\title{
Evidence-Based Psychosocial Treatments for Eating Problems and Eating Disorders
}

\author{
Pamela K. Keel and Alissa Haedt \\ Department of Psychology, University of Iowa
}

\begin{abstract}
Eating disorders represent a significant source of psychological impairment among adolescents. However, most controlled treatment studies have focused on adult populations. This review provides a synthesis of existing data concerning the efficacy of various psychosocial interventions for eating disorders in adolescent samples. Modes of therapy examined in adolescent samples include family therapy, cognitive therapy, behavioral therapy, and cognitive behavioral therapy mostly in patients with anorexia nervosa. At this time, the evidence base is strongest for the Maudsley model of family therapy for anorexia nervosa. Evidence of efficacy for other treatments and other conditions is limited by several methodological factors including the small number of studies, failure to use appropriate control conditions or randomization procedures, and small sample sizes (i.e., fewer than 10 participants per treatment arm). Potential moderators and mediators of treatment effect are reviewed. Finally, results from adolescent studies are contrasted with those from adult studies of eating disorders treatment. Many studies of adult populations comprise late adolescent/young adult participants, suggesting that findings regarding the efficacy of cognitive behavioral therapy for bulimia nervosa in adults likely extend to older adolescent populations.
\end{abstract}

Eating disorders represent a significant source of psychological impairment among adolescent and young adult females with prevalence rates for anorexia nervosa (AN) and bulimia nervosa (BN) falling between $0.5-1 \%$ and $1-3 \%$, respectively (American Psychiatric Association, 2000). AN is defined by refusal to maintain a minimally normal weight (e.g., weight below $85 \%$ of that expected), fear of gaining weight or becoming fat, cognitive distortions regarding weight (e.g., experiencing part or all of the body as fat despite emaciation), and, in postmenarcheal females, loss of three consecutive menstrual cycles (amenorrhea). BN is defined by both binge episodes, in which the person experiences a loss of control over eating and consumes an unusually large

This work was supported by grants from the National Institute of Mental Health (R01 61836; R01 63758; PI: Pamela K. Keel). We thank Kyle De Young and Elizabeth Damstetter for their assistance with the literature search for this article.

Correspondence should be addressed to Pamela K. Keel, Department of Psychology, University of Iowa, E11 Seashore Hall, Iowa City, IA 52242. E-mail: pamela-keel@uiowa.edu amount of food in a short period, and inappropriate compensatory behaviors such as vomiting, laxative use, fasting, or excessive exercise to counteract binge episodes. In BN, self-evaluation is unduly influenced by weight and shape. Beyond the diagnosable eating disorders of $\mathrm{AN}$ and $\mathrm{BN}$, a far larger proportion of adolescents suffer from an eating disorder not otherwise specified (EDNOS; Leon, Fulkerson, Perry, Keel, \& Klump, 1999). Binge eating disorder (BED) is one type of EDNOS that has been proposed as an additional eating disorder diagnosis. BED is defined by recurrent binge episodes in the absence of inappropriate compensatory behaviors. This review summarizes evidence-based psychosocial treatments for eating problems in adolescent patients.

Psychosocial treatments for eating disorders have been designed to address the various components of the disorders. Thus, cognitively oriented therapies have been developed to address distorted cognitions related to body shape and weight that serve to maintain disturbed eating behaviors. Behaviorally oriented therapies have been developed to directly alter food restriction, binge eating, and purging behaviors. Combining these 
approaches, cognitive behavioral therapy (CBT) has been used extensively in controlled treatment studies in adult samples. In contrast, family therapy, described in more detail next, has formed the primary approach to treating eating disorders in adolescent samples.

For this review, treatment outcome studies were identified through electronic and manual literature searches. Electronic searches were employed using PsycINFO and Medline databases from 1985 to the present using the following search terms with the explode option to capture all permutations and subcategory search terms: eating disorders, treatment, and eating. The reference sections of all articles were then reviewed to identify additional relevant articles.

Unlike other articles included in this issue, the topic of eating disorders was not included in the 1998 Journal of Clinical Child Psychology special issue. For this reason, this review includes articles published before 1998. Relevant to study designs used in the area of eating disorders, well-established psychosocial interventions have been demonstrated to be either (a) superior to pill placebo or alternative treatment, or (b) equivalent to an already-established treatment in studies with adequate statistical power in at least two well-conducted group design studies conducted by different investigatory teams (American Psychological Association Task Force for the Promotion and Dissemination of Psychological Procedures, 1995, henceforth referred to as APA Task Force criteria). Probably efficacious psychosocial interventions have been demonstrated to be either (a) more effective than no-treatment control group in at least two well-conducted group design studies conducted by different investigatory teams, or (b) superior to pill placebo or alternative treatment in two group-design studies conducted by the same investigator (APA Task Force criteria, 1995). Thus, studies could include waitlist, standard care, pill placebo, or alternative treatments as control conditions. We also examined evidence for possibly efficacious treatments, defined as those superior to no treatment/waitlist control group in at least one study and possibly efficacious and specific treatments defined as those found to be superior to a rival treatment, and thus specific in their mechanism of action, in at least one study (Chambless \& Ollendick, 2001). The literature search yielded no studies employing a single-case design. Thus, criteria based on such designs were not used in this review.

Table 1 summarizes studies that have evaluated the efficacy of psychosocial interventions. The first column, Type, provides a rating for each study according to the criteria provided by Nathan and Gorman (2002). Relevant to the review presented here, Type 1 studies are the most methodologically rigorous, randomized, controlled trials, which also involve blinded assessments, clearly described inclusion/exclusion criteria and statistical methods, state-of-the-art diagnostic methods, and adequate sample size. Type 2 studies are clinical trials in which some aspects of a Type 1 study are missing. Additional information in tables includes sample size $(N)$, gender distribution (\% female), participant age (mean and range), ethnic/racial diversity of participants, study inclusion and exclusion criteria, treatment conditions (including control conditions), method of assignment to treatment condition, treatment completion rate (by condition whenever possible), outcome domains, results, and qualifications of therapists providing interventions. In addition, Table 1 separates studies with younger adolescent samples $(M$ age $<17)$, who most likely live at home with their families, and studies with older adolescent samples $(M$ age $=17-21)$, who may attend college and live away from home. This distinction is made to examine the differential efficacy of treatments for these age groups.

Table 2 presents the effect size (Cohen's $d$ ) associated with the impact of treatment conditions on eating disorder outcome from each study that provided data concerning pre- and posttreatment means and standard deviations. For within-treatment effect size, we calculated (post $M$-pre $M$ )/pooled $S D$ (Rosenthal \& Rosnow, 1991). For between-treatment effect size in randomized controlled trials, we calculated (Treatment 1 post $M$-Treatment 2 post $M$ )/pooled $S D$ (ThompsonBrenner, Glass, \& Westen, 2003).

\section{SUMMARY OF EMPIRICALLY SUPPORTED PSYCHOSOCIAL INTERVENTIONS}

Examination of Table 1 reveals that family therapy has been studied most for the treatment of eating disorders in younger adolescent samples (Eisler et al., 2000; Geist, Heinmaa, Stephens, Davis, \& Katzman, 2000; le Grange, Crosby, Rathouz, \& Leventhal, 2007; le Grange, Eisler, Dare, \& Russell, 1992; Lock, Agras, Bryson, \& Kraemer, 2005; Robin et al., 1999; Russell, Szmukler, Dare, \& Eisler, 1987). Further, all studies have employed alternative treatment controls rather than waitlist or no-treatment control conditions. Two studies indicated that family therapy was superior for the treatment of AN in adolescents compared to individual therapy (Robin et al., 1999; Russell et al., 1987). The first of these studies (Russell et al., 1987) served as the impetus for much of the subsequent work on $\mathrm{AN}$ and is described first.

\section{Studies in Younger Adolescent Samples With AN}

Russell et al. (1987) compared the efficacy of family therapy and nonspecific individual therapy in patients with AN and BN. Participants with AN had achieved 
a minimally healthy weight during hospitalization prior to random assignment to their treatment condition. Relevant to the present review, participants with AN were subdivided by age, and separate analyses were conducted for adolescents with AN. All patients with BN were adults. Family therapy (currently referred to as the Maudsley model) was an adaptation of Minuchin's family systems therapy (Minuchin, Rosman, \& Baker, 1978) with some key differences. In family systems therapy, the family is viewed as the patient and therapy is designed to alter disturbed family processes that gave rise to the problems in the identified patient (i.e., the adolescent with the eating disorder). In the Maudsley model of family therapy, the family is incorporated into the treatment team.

The Maudsley model of family therapy is broken down into three therapeutic tasks that occur over three phases (Lock, le Grange, Agras, \& Dare, 2001). The first task is to obtain and sustain cooperation from all family members. In this, "the therapist sought to raise the family anxiety about the patient by stressing the specific dangers of her condition, while at the same time countering their tendency to blame themselves" (Russell et al., 1987, p. 1049). The second task is to assess family organization and interactions around eating and the patient's symptoms. The third task is to intervene to help family members change how they respond to the eating disorder to facilitate eating and weight gain in the patient. Techniques used in this task include suggestions and persuasion (through the use of parables, rationalizations, paradoxes, personal authority, and psychodynamic interpretations), behavioral strategies, and homework.

The three phases of therapy have been described by Dare, Eisler, Russell, and Szmukler (1990) as follows:

1. Refeeding the Client: Therapists support and reinforce parents' efforts to refeed their child and encourage parents to form a united front. Meanwhile, siblings are encouraged to be supportive of the patient. Families are encouraged to devise their own plans for refeeding.

2. Negotiations for a New Pattern of Relationships: Once patients show willingness to participate in refeeding and achieve weight gain, weight gain with the least amount of conflict is allowed. Although symptoms remain central to this phase of treatment, other family issues are introduced into therapy. Of note, only issues that impact the parents' ability to ensure patients' weight gain are covered, and issues are covered only to the extent that they are relevant to the patients' symptoms. For example, if family members use deceit as a method to avoid conflict, this pattern would be discussed if it included an adolescent patient lying about her food intake and par- ents accepting her false statements to avoid open conflict.

3. Termination: After the patient achieves a healthy weight, the focus shifts to encouraging a healthy relationship between patients and parents. This is particularly important because, until this point, the patients' illness forms the basis of family interactions. Reflecting the age of patients, themes of increased autonomy, appropriate family boundaries, and preparation for children's departure from home are often covered in this phase.

Because patients had achieved a minimally normal weight during hospitalization, outcome categories indexed patients' ability to sustain healthy weights and continue to make progress toward disorder remission outside of a hospital setting. Good outcome was defined by maintaining weight within $15 \%$ of that expected and return of regular menses. Intermediate outcome was defined by maintaining weight within $15 \%$ of that expected but continued amenorrhea. Poor outcome was defined by a drop in weight to more than $15 \%$ below that expected and/or the development of bulimic symptoms. Among adolescent patients in family therapy, $60 \%(n=6)$ achieved good outcome at 1-year follow-up, and 90\% $(n=9)$ had maintained weight within $15 \%$ of that expected. Among adolescent patients in nonspecific individual therapy, only $9 \%(n=1)$ had achieved good outcome, and $18 \%(n=2)$ had maintained weight within $15 \%$ of that expected (Russell et al., 1987).

These results likely reflected differences in dropout rates between treatments. Family therapy was associated with a $10 \%(n=1)$ dropout rate whereas individual therapy was associated with a $64 \%(n=7)$ dropout rate. However, significant outcome differences between family and individual therapy remained after eliminating patients who had dropped out of treatment during the first 3 months. A limitation of this study was the use of nonmanualized treatments, which undermines standardization of treatment provided. Of note, other data within this study suggest potential differences between adolescent participants randomized to family therapy versus those randomized to individual therapy. Participants randomized to nonspecific individual therapy required significantly longer hospitalization prior to discharge, required more outpatient sessions, and were more likely to receive antidepressant medication compared to those assigned to family treatment. Except for hospitalization, such differences may reflect the superiority of family therapy over individual therapy. Alternatively, differences may reflect that, by chance, a more severely ill group was randomly assigned to individual therapy. Despite these confounds, differences in outcome were maintained at 5-year follow-up: $90 \%$ 
TABLE 1

Summary of Controlled Treatment

\begin{tabular}{|c|c|c|c|c|c|c|c|}
\hline Type & Author & $N$ & $\begin{array}{c}\text { Sex } \\
(\% F)\end{array}$ & $\begin{array}{l}\text { Age } M \\
\text { Range }\end{array}$ & Ethnicity & $\begin{array}{c}\text { Inclusion } \\
\text { Criteria }\end{array}$ & $\begin{array}{c}\text { Exclusion } \\
\text { Criteria }\end{array}$ \\
\hline
\end{tabular}

Younger

Adolescent

Samples

( $M$ age <17)

Eisler et al. (2000)

40

97.5

15.5

$11.5-17.8$

Not reported

- DSM-IV or

ICD-10 AN
- Not reported

\begin{tabular}{|c|c|c|c|c|c|}
\hline $\begin{array}{l}\text { Geist, } \\
\text { Heinmaa, } \\
\text { Stephens, } \\
\text { Davis, \& } \\
\text { Katzman }\end{array}$ & 25 & 100 & $\begin{array}{l}14.6 \\
12-17.3\end{array}$ & Not reported & $\begin{array}{l}\text { - Female } \\
\text { - Age } 12-17.4 \text { years } \\
\text { - Wt }<90 \% \text { IBW } \\
\text { - Self-imposed } \\
\quad \text { food restriction }\end{array}$ \\
\hline
\end{tabular}

Le Grange,

Crosby,

Rathouz, \&

Leventhal

(2007)

$\begin{array}{lll}80 \quad 97.5 \quad 16.1 & 64 \% \text { Cauc } \\ & & 20 \% \text { Hisp } \\ & 11 \% \text { Afr Am } \\ & & 5 \% \text { Other }\end{array}$

- $D S M-I V$ BN

or partial BN

- Age 12-19
- Chronic medical illness

- Immediate suicide risk

- Psychotic features

- Receiving ind or fam tx in community

- Couldn't communicate in English

- Physical/psychiatric disorder requiring hospitalization

- Insufficient knowledge of English language

- Current physical substance dependence

- $\mathrm{BMI} \leq 17.5$

- Current treatment for the eating disorder or current use of med known to influence eating/ weight

- Physical condition or treatments known to influence eating/weight

- $50 \mathrm{mg}$ or more of fluoxetine 


\begin{tabular}{|c|c|c|c|c|c|}
\hline $\begin{array}{l}\text { Treatment } \\
\text { Conditions } \\
\quad(N)\end{array}$ & $\begin{array}{l}\text { Treatment } \\
\text { Assignment }\end{array}$ & $\begin{array}{c}\text { Treatment } \\
\text { Completion } \\
\quad N(\%)\end{array}$ & $\begin{array}{l}\text { Outcome } \\
\text { Measures }\end{array}$ & $\begin{array}{l}\text { Results } \\
\text { Summary }\end{array}$ & Therapists \\
\hline $\begin{array}{l}\text { CFT: } 19 \\
\text { SFT: } 21\end{array}$ & $\begin{array}{l}\text { Stratified } \\
\text { random } \\
\text { assignment }\end{array}$ & $\begin{array}{l}\text { CFT: } 17(89.5 \%) \\
\text { SFT: } 19(90.5 \%)\end{array}$ & $\begin{array}{l}\text { BMI } \\
\text { Bulimic } \\
\quad \text { symptoms } \\
\text { EAT }^{b} \\
\text { EDI }^{c} \\
\text { M-R scales }^{b} \\
\text { M-R outcome } \\
\text { Depression }^{b} \\
\text { MOCI }^{c} \\
\text { Obsessionality }^{b} \\
\text { RSE }^{c} \\
\text { SMFQ }^{c} \\
\text { Tension }^{b}\end{array}$ & $\begin{array}{l}\text { CFT }>\text { SFT on } \\
\text { EDI } \\
\text { CFT }=\text { SFT on } \\
\text { BMI } \\
\text { Bulimic } \\
\text { symptoms } \\
\text { EAT } \\
\text { M-R scales } \\
\text { M-R outcome } \\
\text { CFT }>\text { SFT on } \\
\text { Depression } \\
\text { Obsessionality } \\
\text { SMFQ } \\
\text { CFT = SFT } \\
\text { MOCI } \\
\text { RSE } \\
\text { Tension }\end{array}$ & Not reported \\
\hline $\begin{array}{l}\text { FT: } 12 \\
\text { FPE: } 13\end{array}$ & $\begin{array}{l}\text { Random } \\
\text { assignment }\end{array}$ & $25(100 \%)$ & $\begin{array}{l}\% \text { ABW } \\
\mathrm{EDI}^{c} 2^{c} \\
\mathrm{BSI}^{c, d} \\
\mathrm{CDI}^{c} \\
\mathrm{FAM}^{c} \mathrm{III}^{c, d},\end{array}$ & $\mathrm{FT}=\mathrm{FPE}$ & $\begin{array}{l}\text { FT: } 2 \text { social } \\
\text { workers, } \\
1 \text { psychiatrist } \\
\text { FPE: dietician, } \\
\text { occupational } \\
\text { therapist, } \\
\text { psychiatric nurse }\end{array}$ \\
\hline $\begin{array}{l}\text { FT: } 41 \\
\text { SPT: } 39\end{array}$ & $\begin{array}{l}\text { Stratified } \\
\text { random } \\
\text { assignment }\end{array}$ & $\begin{array}{l}\text { FT: } 36 \\
\quad(87.8 \%) \\
\text { SPT: } 35 \\
\quad(89.7 \%)\end{array}$ & $\begin{array}{l}\% \text { remitted }^{b} \\
\mathrm{EDE}^{b} \\
\mathrm{BDI}^{c} \\
\mathrm{RSE}^{c}\end{array}$ & $\begin{array}{l}\mathrm{FT}>\mathrm{SPT} \text { on } \\
\% \text { remitted } \\
\text { EDE subscales } \\
\mathrm{FT}=\mathrm{SPT} \text { on } \\
\text { BDI } \\
\text { RSE }\end{array}$ & $\begin{array}{l}5 \mathrm{PhD} \text { psychologists } \\
3 \text { child psychiatry } \\
\text { fellows }\end{array}$ \\
\hline
\end{tabular}


TABLE 1

Continued

\begin{tabular}{|c|c|c|c|c|c|c|c|}
\hline Type & Author & $N$ & $\begin{array}{l}\text { Sex } \\
(\% F)\end{array}$ & $\begin{array}{l}\text { Age } M \\
\text { Range }\end{array}$ & Ethnicity & $\begin{array}{c}\text { Inclusion } \\
\text { Criteria }\end{array}$ & $\begin{array}{l}\text { Exclusion } \\
\text { Criteria }\end{array}$ \\
\hline 2 & $\begin{array}{l}\text { Le Grange, } \\
\text { Eisler, } \\
\text { Dare, \& } \\
\text { Russell } \\
\text { (1992) }\end{array}$ & 18 & 88.9 & $\begin{array}{l}15.3 \\
12-17\end{array}$ & Not reported & $\begin{array}{l}\text { - } D S M-I I I-R \text { AN } \\
\text { - Age }<18 \\
\text { - Duration of } \\
\text { illness shorter } \\
\text { than } 3 \text { years }\end{array}$ & $\begin{array}{l}\text { - Medical state or } \\
\text { risk of suicide } \\
\text { warranted } \\
\text { hospitalization } \\
\text { - Another major } \\
\text { psychiatric } \\
\text { disorder } \\
\text { coexisted }\end{array}$ \\
\hline 1 & $\begin{array}{c}\text { Lock, Agras, } \\
\text { Bryson, \& } \\
\text { Kraemer } \\
(2005)\end{array}$ & 86 & 89.5 & $\begin{array}{l}15.2 \\
12-18\end{array}$ & $\begin{array}{l}74 \% \text { Cauc } \\
9 \% \text { Asian } \\
12 \% \text { Hisp } \\
1 \% \text { Nat Am } \\
4 \% \text { Other }\end{array}$ & $\begin{array}{l}\text { - } D S M-I V \text { AN } \\
\text { - Some partially } \\
\text { weight restored } \\
\text { - Loss of } 1 \\
\text { menstrual cycle }\end{array}$ & $\begin{array}{l}\text { - Severe physical } \\
\text { health problems } \\
\text { likely to affect } \\
\text { weight (diabetes) } \\
\text { - Psychiatric } \\
\text { illness that } \\
\text { would interfere } \\
\text { w/tx (psychosis) } \\
\text { - Failed fam tx } \\
\text { in past } \\
\text { - Receiving } \\
\text { other psychotherapy }\end{array}$ \\
\hline 2 & $\begin{array}{l}\text { Robin et al. } \\
\text { (1999) }\end{array}$ & 41 & 100 & 14.2 & $\begin{array}{l}94.6 \% \text { Cauc } \\
5.4 \% \text { Middle } \\
\text { Eastern }\end{array}$ & $\begin{array}{l}\text { - } D S M-I I I-R \text { AN } \\
\text { - Females } \\
\text { - Age } 11-20 \\
\text { - Residing } \\
\text { at home w/ } 1 \\
\text { or both parents }\end{array}$ & - Not reported \\
\hline 2 & $\begin{array}{l}\text { Russell, } \\
\text { Szmukler, } \\
\text { Dare, \& } \\
\text { Eisler } \\
(1987)^{e}\end{array}$ & 21 & 91.3 & 16.6 & Not reported & $\begin{array}{l}\text { - } D S M \text {-III AN } \\
\text { - Extreme loss } \\
\text { of wt, no } \\
\text { purging } \\
\text { following } \\
\text { overeating } \\
\text { - Amenorrhea } \\
\text { or loss of sex } \\
\text { interest/potency }\end{array}$ & - Not reported \\
\hline $\begin{array}{r}\text { Older } \\
\text { Adc } \\
\text { San } \\
(M \\
17-\end{array}$ & & & & & & & \\
\hline 2 & $\begin{array}{l}\text { Bachar, } \\
\text { Latzer, } \\
\text { Kreitler, \& } \\
\text { Berry } \\
\text { (1999) }\end{array}$ & 13 & 100 & 18.1 & Not reported & - $D S M-I V \mathrm{AN}$ & $\begin{array}{l}\text { - Comorbid axis } \\
\text { I disorder }\end{array}$ \\
\hline 2 & $\begin{array}{l}\text { Okamoto } \\
\text { et al. } \\
(2002)\end{array}$ & 35 & 100 & 19.6 & Not reported & - $D S M-I V$ AN & - Not reported \\
\hline
\end{tabular}




\begin{tabular}{|c|c|c|c|c|c|}
\hline $\begin{array}{l}\text { Treatment } \\
\text { Conditions } \\
\quad(N)\end{array}$ & $\begin{array}{l}\text { Treatment } \\
\text { Assignment }\end{array}$ & $\begin{array}{c}\text { Treatment } \\
\text { Completion } \\
N(\%)\end{array}$ & $\begin{array}{l}\text { Outcome } \\
\text { Measures }\end{array}$ & $\begin{array}{l}\text { Results } \\
\text { Summary }\end{array}$ & Therapists \\
\hline $\begin{array}{l}\text { CFT: } 9 \\
\text { FT: } 9\end{array}$ & $\begin{array}{l}\text { Random } \\
\text { assignment }\end{array}$ & $\begin{array}{l}\text { CFT: } 9(100 \%) \\
\text { SFT: } 9(100 \%)\end{array}$ & $\begin{array}{l}\% \text { ABW } \\
\text { EAT }^{c} \\
\text { Menstrual status }^{b} \\
\text { M-R assessment } \\
\quad \text { schedule }^{b} \\
\text { M-R outcome } \\
\text { RSE }^{c}\end{array}$ & $\mathrm{CFT}=\mathrm{SFT}$ & $\begin{array}{l}2 \text { clinical } \\
\text { psychologists } \\
1 \text { psychiatrist, } \\
1 \text { social worker }\end{array}$ \\
\hline $\begin{array}{l}\text { STFT: } 44 \\
\text { LTFT: } 42\end{array}$ & $\begin{array}{l}\text { Stratified } \\
\text { random } \\
\text { assignment }\end{array}$ & $\begin{array}{l}\text { STFT: } 42(96 \%) \\
\text { LTFT: } 35(84 \%)\end{array}$ & $\begin{array}{l}\text { BMI } \\
\text { EDE }^{b} \\
\text { YBC-ED }^{b} \\
\text { CBCL }^{d} \\
\text { SADS-SAC }^{b} \\
\text { YSR }^{c}\end{array}$ & $\mathrm{STFT}=\mathrm{LTFT}$ & $\begin{array}{c}3 \text { master's-level } \\
\text { psychologist, } \\
1 \text { child and } \\
\text { adolescent } \\
\text { psychiatrist }\end{array}$ \\
\hline $\begin{array}{l}\text { BFST: } 19 \\
\text { EOIT: } 18\end{array}$ & $\begin{array}{l}\text { Random } \\
\text { assignment }\end{array}$ & $37(90.2 \%)$ & $\begin{array}{l}\mathrm{BMI}^{c, d} \\
\mathrm{EAT}^{c} \\
\mathrm{EDI}^{c} \\
\mathrm{BDI}^{c} \\
\mathrm{CBCL}^{d}\end{array}$ & $\begin{array}{l}\text { BFST }>\text { EOIT } \\
\text { on BMI } \\
\text { BFST }=\text { EOIT on } \\
\text { EAT } \\
\text { EDI } \\
\text { BFST }=\text { EOIT on } \\
\text { BDI CBCL }\end{array}$ & $\begin{array}{l}4 \mathrm{PhD} \\
\text { psychologists, } \\
1 \text { master's-level } \\
\text { social worker; } \\
\text { all female }\end{array}$ \\
\hline $\begin{array}{l}\text { FT: } 10 \\
\text { IT: } 11\end{array}$ & $\begin{array}{l}\text { Random } \\
\text { assignment }\end{array}$ & $\begin{array}{l}\text { FT: } 10(100 \%) \\
\text { IT: } 11(100 \%)\end{array}$ & $\begin{array}{l}\% \text { ABW } \\
\text { M-R scales } \\
\text { M-R outcome }\end{array}$ & $\begin{array}{l}\mathrm{FT}>\mathrm{IT} \text { on } \\
\% \text { ABW } \\
\text { M-R scales } \\
\text { M-R outcome }\end{array}$ & $\begin{array}{r}3 \text { social workers, } \\
1 \text { psychologist }\end{array}$ \\
\hline $\begin{array}{l}\text { SPT: } 7 \\
\text { COT: } 6\end{array}$ & $\begin{array}{l}\text { Random } \\
\text { assignment }\end{array}$ & $\begin{array}{l}\text { SPT: } 6(85.7 \%) \\
\text { COT: } 2(33.3 \%)\end{array}$ & $\begin{array}{l}\text { DSM-SS } \\
{\text { EAT } 26^{c}}^{b} \\
\% \text { remitted }^{b} \\
\text { BSI }^{1} \\
\text { Selves Q'naire }^{c}\end{array}$ & $\begin{array}{l}N \text { too small for } \\
\text { inferential } \\
\text { statistics }\end{array}$ & $\begin{array}{l}7 \text { residents in } \\
\text { clinical } \\
\text { psychology } \\
\text { with master's } \\
\text { degree, } \\
2 \text { psychiatric } \\
\text { social workers, } \\
1 \text { psychiatrist }\end{array}$ \\
\hline $\begin{array}{l}\text { Fukamachi's } \\
\text { ART: } 7 \\
\text { ART + TET: } 7 \\
\text { KPT: } 21\end{array}$ & Not random & $\begin{array}{l}\text { ART: } 7(100 \%) \\
\text { TET: } 7(100 \%) \\
\text { KPT: } 21(100 \%)\end{array}$ & BMI & $\begin{array}{c}\mathrm{KPT}>\mathrm{ART} \\
\mathrm{TET}=\mathrm{KPT}, \\
\mathrm{ART}\end{array}$ & Not reported \\
\hline
\end{tabular}


TABLE 1

Continued

\begin{tabular}{|c|c|c|c|c|c|c|c|}
\hline Tyре & Author & $N$ & $\begin{array}{l}\text { Sex } \\
(\% F)\end{array}$ & $\begin{array}{l}\text { Age } M \\
\text { Range }\end{array}$ & Ethnicity & $\begin{array}{c}\text { Inclusion } \\
\text { Criteria }\end{array}$ & $\begin{array}{c}\text { Exclusion } \\
\text { Criteria }\end{array}$ \\
\hline 2 & $\begin{array}{l}\text { Perpina et al. } \\
\text { (1999) }\end{array}$ & 18 & & 17.5 & Not reported & $\begin{array}{l}\text { - } D S M-I V \text { eating } \\
\text { disorder } \\
\text { - Not in a } \\
\text { critical stage } \\
\text { of ED (life } \\
\text { not at risk) }\end{array}$ & - Not reported \\
\hline
\end{tabular}

1

\begin{tabular}{l}
$\begin{array}{l}\text { Schmidt et al. } \\
\text { (2007) }\end{array}$ \\
\hline
\end{tabular}

$3 \%$ Other

Not reported
- Age $>16$

- DSM-III-R

AN
- BMI $<10$ th \%ile

- Insufficient knowledge of English language

- Learning disability

- Severe mental illness

- Substance

dependence

Serfaty,
Turkington,
Heap,
Ledsham, \&
Jolley (1999)

Note: Superscripts indicate who completed each outcome measure; no superscript indicates that outcome was objectively measured. DSM = family therapy; SFT = separated family therapy; BMI = body mass index; EAT = Eating Attitudes Test; EDI = Eating Disorders Inventory; Mood and Feeling Questionnaire; wt = weight; IBW = ideal body weight; FT = family therapy; FPE = family group psychoeducation; ind = FAM-III = Family Assessment Measure Cauc $=$ Caucasian; Hisp $=$ Hispanic; Afr Am $=$ African American; BN $=$ bulimia nervosa; SPT $=$ term family therapy; LTFT = long-term family therapy; YBC-ED = Yale-Brown-Cornell Eating Disorder Scale; CBCL $=$ Child Behavior Checklist; systems therapy; EOIT = ego-oriented individual therapy; IT = nonspecific individual treatment; COT = cognitive orientation treatment; Prefectural University of Medicine behavior therapy; ED = eating disorder; RT = relaxation training; VR = virtual reality; ASI = Appearance ance Questionnaire; BIATQ = Body Image Automatic Thoughts Questionnaire; BITE $=$ Bulimic Investigatory Test Edinburgh; BSQ $=$ Body PANAS = Positive and Negative Affect Schedule; EDNOS = eating disorder not otherwise specified; CT $=$ cognitive therapy; DC $=$ dietician

${ }^{b}$ Patient self-report. ${ }^{c}$ Patient rated. ${ }^{d}$ Clinician rated. ${ }^{e}$ Russell et al. (1987) consisted of three groups; the adolescent AN group 


\begin{tabular}{|c|c|c|c|c|c|}
\hline $\begin{array}{l}\text { Treatment } \\
\text { Conditions } \\
\quad(N)\end{array}$ & $\begin{array}{l}\text { Treatment } \\
\text { Assignment }\end{array}$ & $\begin{array}{c}\text { Treatment } \\
\text { Completion } \\
\quad N(\%)\end{array}$ & $\begin{array}{l}\text { Outcome } \\
\text { Measures }\end{array}$ & $\begin{array}{l}\text { Results } \\
\text { Summary }\end{array}$ & Therapists \\
\hline $\begin{array}{l}\text { Cash's body } \\
\text { image treatment } \\
+ \text { RT: } 9 \\
\text { Cash's body image } \\
\text { treatment }+ \\
\text { VR: } 9\end{array}$ & $\begin{array}{l}\text { Random } \\
\text { assignment }\end{array}$ & $\begin{array}{l}\text { RT: } 5(55.6 \%) \\
\text { VR: } 8(88.9 \%)\end{array}$ & $\begin{array}{l}\text { ASI }^{c} \\
\text { BASS }^{c} \\
\text { BAT }^{c} \\
\text { BES }^{c} \\
\text { BIAQ }^{c} \\
\text { BIATQ }^{c} \\
\text { BITE }^{c} \\
\text { Body } \\
\quad \text { Interference }^{c} \\
\text { BSQ }^{c} \\
\text { EAT }^{c} \\
\text { EDI-2 }^{c} \\
\text { Fear of putting } \\
\text { on wt }^{c} \\
\text { RS }^{c} \\
\text { SIBID }^{c} \\
\text { BDI }^{c} \\
\text { PANAS }^{c}\end{array}$ & $\begin{array}{l}\text { VR }>\text { RT on } \\
\quad \text { BASS } \\
\text { BIAQ } \\
\text { BIATQ } \\
\text { BSQ } \\
\text { SIBID } \\
\text { Fear of } \\
\quad \text { putting on wt } \\
\text { BDI } \\
\text { PANAS } \\
\text { VR = RT on } \\
\quad \text { ASI } \\
\text { BAT } \\
\text { BES } \\
\text { BITE } \\
\text { Body interference } \\
\text { EAT } \\
\text { EDI-2 RS }\end{array}$ & Not reported \\
\hline $\begin{array}{l}\text { FT: } 41 \\
\text { CBT Guided } \\
\text { Self-Care: } 44\end{array}$ & $\begin{array}{l}\text { Random } \\
\text { assignment }\end{array}$ & $\begin{array}{l}\text { FT: } 29(70.7 \%) \\
\text { CBT: } 31 \\
\quad(70.5 \%)\end{array}$ & $\begin{array}{l}\text { Bingeing } \\
\quad \text { abstinence } \\
\text { BMI } \\
\text { Fasting }^{c} \\
\text { Food-related }^{b} \text { fear }^{c} \\
\text { Food-related }^{\text {preoccupation }}{ }^{c} \\
\text { Strict dieting }^{c} \\
\text { Vomiting }^{\text {abstinence }}{ }^{b} \\
\text { Wt/shape } \\
\text { concerns }\end{array}$ & $\begin{array}{l}\mathrm{CBT}>\mathrm{FT} \text { on } \\
\text { Bingeing } \\
\mathrm{CBT}=\mathrm{FT} \text { on } \\
\text { All other } \\
\text { measures }\end{array}$ & $\begin{array}{l}23 \text { experienced } \\
\text { therapists } \\
\text { trained in } \\
\text { both therapies }\end{array}$ \\
\hline $\begin{array}{l}\text { CT: } 25 \\
\text { DC: } 10\end{array}$ & $\begin{array}{l}\text { Random } \\
\text { assignment }\end{array}$ & $\begin{array}{l}\text { CT: } 23(92 \%) \\
\text { DC: } 0(0 \%)\end{array}$ & $\begin{array}{l}\text { BMI } \\
\text { EDI }^{c} \\
\% \text { remitted }^{b} \\
\text { BDI }^{c} \\
\text { DAS }^{c} \\
\text { LCB }^{c}\end{array}$ & $\begin{array}{l}\mathrm{CT}>\mathrm{DC} \text { on } \\
\% \text { remitted } \\
\mathrm{CT}=\mathrm{DC} \text { on } \\
\quad \mathrm{BMI} \\
\text { Not reported } \\
\text { EDI } \\
\text { BDI } \\
\text { DAS } \\
\text { LCB }\end{array}$ & $\begin{array}{l}\text { Psychiatrist (DT), } \\
\text { psychologist } \\
\text { (MH), nurse } \\
\text { behavior therapist } \\
\text { (LL) }\end{array}$ \\
\hline
\end{tabular}

Diagnostic and Statistical Manual of Mental Disorders; ICD = International Classification of Diseases; AN = anorexia nervosa; CFT = conjoint $\mathrm{M}-\mathrm{R}=$ Morgan \& Russell scales; MOCI = Maudsley Obsessional Compulsive Index; RSE = Rosenberg Self Esteem Inventory; SMFQ = Short individual; fam = family; tx = treatment; ABW = average body weight; BSI = Brief Symptom Inventory; CDI = Children's Depression Inventory; supportive psychotherapy; EDE = Eating Disorder Examination; BDI = Beck Depression Inventory; Nat Am = Native American; STFT = shortSADS-SAC = Schedule for Affective Disorders and Schizophrenia for School-Age Children; YSR = Youth Self-Report; BFST = behavioral family DSM-SS = DSM Symptomatology Scale for Anorexia and Bulimia; ART = activity restriction therapy; TET = token economy; KPT $=$ Kyoto Schemas Inventory; BASS = Body Areas Satisfaction Scale; BAT = Body Attitudes Test; BES = Body Esteem Scale; BIAQ = Body Image AvoidShape Questionnaire; RS = Restrained Scale; SIBID = Situational Inventory of Body Image Dysphoria; BDI = Beck Depression Inventory; control; DAS = Dysfunctional Attitudes Scale; LCB = Locus of Control of Behaviour. is reported in this table (see Table 3 for the adult $\mathrm{AN}$ and adult $\mathrm{BN}$ group results). 
TABLE 2

Effect Sizes Associated With Different Treatments for Adolescent Patients With Eating Disorders

\begin{tabular}{|c|c|c|c|c|c|c|}
\hline Study (Eating Disorder) & Treatment & $N$ & $\begin{array}{l}\text { Weight } \\
\text { Change } \\
\text { Cohen's d }\end{array}$ & $\begin{array}{c}\text { Body } \\
\text { Image } \\
\text { Disturbance } \\
\text { Cohen's d }\end{array}$ & $\begin{array}{l}\text { Bulimic } \\
\text { Symptoms } \\
\text { Cohen's d }\end{array}$ & $\begin{array}{l}\text { Composite } \\
\text { Score } \\
\text { Cohen's d }\end{array}$ \\
\hline Eisler et al. (2000) & Separated family therapy & 21 & $1.50^{a}$ & & $.64^{b}$ & $.80^{c}, 1.17^{d}$ \\
\hline \multirow[t]{2}{*}{ (Anorexia nervosa) } & Conjoint family therapy & 19 & $.96^{a}$ & & $.34^{b}$ & $1.25^{c}, 1.29^{d}$ \\
\hline & SFT vs. CFT & & $.49^{a, *}$ & & $.13^{b}$ & $-.40^{c}, .10^{d}$ \\
\hline Geist et al. (2000) & Family group psychoeducation & 13 & $1.96^{e}$ & $.06^{f},-.22^{g}$ & $-.28^{h}$ & \\
\hline \multirow[t]{2}{*}{ (Anorexia nervosa) } & Family therapy & 12 & $1.98^{e}$ & $-.18^{f},-.19^{g}$ & $.00^{h}$ & \\
\hline & FPE vs. FT & & $.64^{e}$ & $-.13^{f},-.21^{g}$ & $-.56^{h}$ & \\
\hline Le Grange et al. (1992) & Separated family therapy & 9 & $2.67^{e}$ & & & $1.13^{d}$ \\
\hline \multirow[t]{2}{*}{ (Anorexia nervosa) } & Conjoint family therapy & 9 & $1.16^{e}$ & & & $.95^{d}$ \\
\hline & SFT vs. CFT & & $.98^{e}$ & & & $.09^{d}$ \\
\hline Le Grange et al. (2007) & Family therapy & 41 & & $1.23^{i}, 1.47^{j}$ & $.63^{k}, .53^{l}$ & $1.68^{m}$ \\
\hline \multirow[t]{2}{*}{ (Bulimia nervosa) } & Supportive psychotherapy & 39 & & $1.00^{i}, 1.06^{j}$ & $.95^{k}, .77^{l}$ & $1.20^{m}$ \\
\hline & FT vs. SPT & & & $.48^{j}, .55^{j}$ & $-.08^{k}, .72^{l}$ & $.50^{m}$ \\
\hline Lock et al. (2005) & Long-term family therapy & 42 & $1.21^{a}$ & $.39^{i, j}$ & & \\
\hline \multirow{2}{*}{ (Anorexia nervosa) } & Short-term family therapy & 44 & $1.38^{a}$ & $.23^{i}, .31^{j}$ & & \\
\hline & LTFT vs. STFT & & $0.0^{a}$ & $.38^{i}, .19^{j}$ & & \\
\hline Okamoto et al. $(2002)^{n}$ & Activity restriction therapy (ART) & 7 & $.99^{a}$ & & & \\
\hline \multirow[t]{2}{*}{ (Anorexia nervosa) } & $\mathrm{ART}+$ token economy & 7 & $1.71^{a}$ & & & \\
\hline & behavior therapy & 21 & $1.91^{a}$ & & & \\
\hline Robin et al. (1999) & Behavioral family systems therapy & 19 & $2.54^{a}$ & & & $1.46^{d}$ \\
\hline \multirow[t]{2}{*}{ (Anorexia nervosa) } & Ego-oriented individual therapy & 18 & $1.15^{a}$ & & & $.98^{d}$ \\
\hline & BFST vs. EOIT & & $.53^{a}$ & & & $-.28^{\mathrm{d}}$ \\
\hline Russell et al. (1987) & Family therapy & 10 & $.44^{e}$ & & & \\
\hline \multirow[t]{2}{*}{ (Anorexia nervosa) } & Nonspecific individual therapy & 11 & $-.69^{e}$ & & & \\
\hline & FT vs. IT & & $1.03^{e}$ & & & \\
\hline Schmidt et al. (2007) & Family therapy & 41 & $.22^{a}$ & $.08^{\circ}$ & & \\
\hline \multirow{2}{*}{ (Bulimia nervosa) } & CBT guided self-care & 44 & $-.18^{a}$ & $.54^{\circ}$ & & \\
\hline & FT vs. CBT & & $.34^{a}$ & $-.40^{\circ}$ & $-.21^{p}$ & \\
\hline & Cognitive therapy & 25 & $.80^{a}$ & $.37^{f}, .00^{g}$ & $.14^{h}$ & $.30^{c}$ \\
\hline \multirow[t]{2}{*}{ (Anorexia nervosa) } & Dietician control & 10 & & & & \\
\hline & CT vs. $\mathrm{DC}^{q}$ & & $.72^{a}$ & & & \\
\hline
\end{tabular}

Note: Results from Bachar et al. (1999) are not reported because analyses included adult women with bulimia nervosa; results from Perpina et al. (1999) are not included because statistics were not reported. Global EDE scores were not reported in Lock et al. (2005). Positive within-treatment effect sizes reflect increases in weight, decreases in body image disturbance, decreases in bulimic symptoms, and decreases in composite scores (i.e., better outcome). Positive between-treatment effect sizes indicate better outcome associated with the first treatment listed compared to the second treatment listed in the comparison. Superscripts indicate which measure was used to calculate Cohen's $d$.

${ }^{a}$ Body mass index (BMI). ${ }^{b}$ Bulimic symptoms. ${ }^{c}$ Eating Disorders Inventory (EDI) total score. ${ }^{d}$ Eating Attitudes Test (EAT) total score. ${ }^{e}$ Percentage average body weight ${ }^{f}$ EDI drive for Thinness subscale. ${ }^{g}$ EDI Body Dissatisfaction subscale. ${ }^{h}$ EDI Bulimia subscale. ${ }^{i}$ Eating Disorders Examination (EDE) Weight Concerns subscale. ${ }^{j}$ EDE Shape Concerns subscale. ${ }^{k}$ EDE objective binge frequency. ${ }^{l}$ EDE compensatory behavior frequency. ${ }^{m}$ EDE global score. ${ }^{n}$ Between-treatment effect sizes were not calculated because of nonrandom assignment to conditions. ${ }^{o}$ Inappropriate weight and shape concerns. ${ }^{p}$ Effect size reported by Schmidt et al. (2007) for difference in abstinence from binge eating assessed by EATATE interview. ${ }^{q}$ Between-treatment BMI effect size for Serfaty et al. (1999) reflects BMI at last observation because all participants in the dietician control condition dropped out. This study did not report pretreatment BMI in the dietician control condition. Thus, no effect size for change in weight is reported for this condition.

*Bold face indicates effect sizes for comparisons between treatments.

$(n=9)$ of patients in family therapy had achieved good outcomes compared to $36 \%(n=4)$ of patients in nonspecific individual therapy (Eisler et al., 1997).

Robin et al. (1999) replicated the superiority of a behavioral family systems therapy based on the Maudsley model of family therapy (Russell et al., 1987) to egooriented individual therapy in adolescent patients with AN. Ego-oriented individual therapy involved individual therapy sessions in which the therapist emphasized (a) strength to help the adolescent, (b) respect for the adolescent's autonomy, (c) no pressure for the adolescent to gain weight or change attitudes, (d) help for the adolescent to understand how to choose to be healthy, and (e) instruction for coping with a "dysfunctional family" and "inner fears" (Robin et al., 1999). Unlike Russell et al., Robin et al. initiated therapy with patients immediately after intake assessments when patients were underweight. Patients were hospitalized during the course of the study if weight dropped below $75 \%$ of that expected or significant cardiac problems emerged. If hospitalization occurred, patients continued to receive their assigned treatment condition and were 
released once they reached a minimum of $80 \%$ expected body weight and no longer evidenced acute medical risk. Although the two treatments did not differ significantly in producing improvements in scores on a composite measure of eating disordered attitudes and behaviors (the Eating Attitudes Test [EAT]; Garner \& Garfinkel, 1979), the behavioral family systems therapy condition produced significantly greater weight gain compared to the ego-oriented individual therapy at posttreatment.

One criticism of this study has been that $58 \%$ $(n=11)$ of patients randomized to behavioral family systems therapy versus $28 \%(n=5)$ of patients randomized to ego-oriented individual therapy received inpatient treatment and that hospitalization, rather than family therapy, may have accounted for differences in weight gain (Shafran, Keel, Haedt, \& Fairburn, in press). In addition, patients in family therapy were significantly older than patients in ego-oriented individual therapy (14.9 vs. 13.4 years). Further limitations include a small sample size, large number of therapists, and long recruitment period. However, results from this study are consistent with those of Russell et al. (1987), and differences in weight gain were maintained at 1-year followup (Robin et al., 1999). Thus, family-based therapies have been found to be superior to alternative treatment in two separate studies and represent well-established interventions for treatment of $\mathrm{AN}$ in adolescents, according to APA Task Force criteria (1995).

Several studies have sought to enhance the efficacy of family therapy for adolescent AN by comparing different forms of family therapy. Le Grange et al. (1992) compared conjoint family therapy, as used in the Russell et al. (1987) study, and a separated family therapy. The separated family therapy provided individual counseling to the patient with AN and then provided counseling to parents at a different time. Information provided to parents was the same in the two treatments with the exception that the therapist had no opportunity to view the family as a system or provide feedback on dynamics within the family system in the separated family condition. This study found no significant differences in response between treatment conditions; patients within both treatments demonstrated significant improvements in weight and on the EAT (le Grange et al., 1992).

In contrast, Eisler et al. (2000) found some significant differences between conjoint and separated family therapy (described previously), including greater improvements in patient-reported Eating Disorder Inventory scores for the former. However, no significant differences were found for improvements in weight, bulimic symptoms, or patient-reported EAT scores. Notably, Eisler et al. (2000) also reported that separated family therapy was superior to conjoint family therapy for patients with high levels of maternal criticism. Thus, level of maternal criticism may be an important factor in treatment selection. Treatment response was maintained at 5-year follow-up of this sample (Eisler, Simic, Russell, \& Dare, 2007) and did not differ between conjoint and separated family therapy. However, as with initial treatment response, family expressed emotion moderated 5-year treatment outcome. Separated family therapy was superior to conjoint family therapy in patients from high expressed emotion families, whereas no difference between treatments was found for low expressed emotion families at 5-year follow-up. Taken together, results from these studies (Eisler et al., 2000; le Grange et al., 1992) suggest that the benefits of familybased interventions may come from inviting parents to become part of the treatment team rather than viewing the family as the patient. Supporting this conclusion, Geist et al. (2000) did not find a significant difference in treatment response for inpatients assigned to a conjoint family therapy versus a family group psychoeducation program in which families attended classes together but patients were separated from parents in group discussions of topics raised during classes.

The most recent study of the Maudsley model of family therapy in AN (Lock et al., 2005) compared a short-term (10 sessions over 6 months) to a long-term (20 sessions over 12 months) family therapy condition. Across studies, family therapy has ranged from 6 months to 3 years (Lock \& le Grange, 2001). Thus, Lock et al. (2005) sought to understand the impact of treatment duration on outcome. Participants were included if they met full criteria for AN based on the fourth edition of the Diagnostic and Statistical Manual of Mental Disorders (DSM-IV; American Psychiatric Association, 1994) or if they fell short of a full AN diagnosis because of partial weight restoration during hospitalization and/or failure to meet the amenorrhea criterion. Participants in both therapies demonstrated significant improvements over the course of the study and at 12-month follow-up. Participants in both conditions reported significant decreases in body image disturbance assessed by the Eating Disorders Examination (EDE) interview in addition to significant weight gain, and there were no significant differences between patients in the short-term versus long-term family therapy conditions at posttreatment or 2- to 6-year follow-up ( $M$ follow-up $=3.96$ years; Lock, Couturier, \& Agras, 2006). It is noteworthy that large effect sizes are observed across most studies utilizing family therapy, particularly for weight gain and decreases in composite eating pathology scores (see Table 2). The one exception is the small effect size for change in weight reported by Russell et al. (1987), in which all patients had been restored to a healthy body weight before initiating outpatient family therapy. 


\section{Studies in Older Adolescent Samples With AN}

Tables 1 and 2 also include studies with older adolescent samples, defined as a mean age between 17 and 21 years. In a study of older adolescent patients with AN, Serfaty, Turkington, Heap, Ledsham, and Jolley (1999) compared the efficacy of individual cognitive therapy to dietary counseling. Because of the greater availability of cognitive therapists compared to nutritional counselors, patients were randomized to cognitive therapy versus dietary counseling at a 3:1 ratio. Cognitive therapists followed a manualized approach in which they employed a combination of cognitive and behavioral techniques. Therapists worked collaboratively with patients to set goals for a target weight and rate of gradual weight gain $(0.5-1.0 \mathrm{~kg} /$ week). Schema level interventions (i.e., interventions at the level of mental sets) were used to address body image, self-esteem, and problems with identification of emotional states. The most common schemas addressed in therapy were related to control, achievement, and approval. Finally, therapists worked with patients on relapse prevention.

After 3 months of treatment, $8 \%(n=2)$ of patients had dropped out of cognitive therapy compared to $100 \%(n=10)$ of patients assigned to dietary counseling. Using intent-to-treat analyses, in which data from all patients entered into the study are used, the authors found significant differences between conditions in the proportion of patients who had achieved remission $(56 \%, n=14$ in cognitive therapy vs. $0 \%$ in dietary counseling) but no significant differences in body mass index $\left(17.7 \mathrm{~kg} / \mathrm{m}^{2}\right.$ in cognitive therapy vs. $15.9 \mathrm{~kg} / \mathrm{m}^{2}$ in dietary counseling). Thus, results seem to favor cognitive therapy over dietary counseling. Of note, participants randomly allocated to the two groups differed in mean age at intake (22.1 years in cognitive therapy vs. 17.9 years in dietary counseling). Although the difference was not statistically significant, mean ages indicate that the cognitive therapy condition comprised a young adult sample. Thus, conclusions regarding the efficacy of cognitive therapy for younger adolescent patients with AN cannot be made.

Bachar, Latzer, Kreitler, and Berry (1999) compared the efficacy of nondirective psychoanalytic psychotherapy based on the work of Heinz Kohut (1977; Self Psychology) to the efficacy of a cognitive orientation therapy based on the work of Kreitler and Kreitler (1990) in patients with AN who were mostly adolescents. $^{1}$ In the nondirective psychoanalytic self psychology condition, eating disordered behavior was

\footnotetext{
${ }^{1}$ This study also included patients with $\mathrm{BN}$ who were mostly adults ( $M$ age $=24$ years). Among all patients, participants randomized to self psychology therapy achieved significantly greater reductions in EAT scores compared to participants randomized to cognitive orientation therapy.
}

viewed as a consequence of people substituting food for people to meet the needs of regulating self-esteem, self-nurturance, and vitalization. In cognitive orientation therapy, the therapist examined "the meaning of a behavior" (p. 116). For example, the therapist directed patients to indicate how much they believed that overeating resulted from avoiding the overt expression of hostility. The therapist then worked to change beliefs related to the themes (e.g., beliefs about avoidance and aggression) but did not discuss anything directly related to eating behavior or attitudes toward weight or shape (Bachar et al., 1999). Thus, the cognitive orientation therapy differed from both the cognitive therapy employed by Serfaty et al. (1999) and from CBT used in many studies of adult $\mathrm{BN}$ patients.

Among patients with AN, 28\% $(n=1)$ dropped out or had to be withdrawn from the self psychology condition whereas $67 \%(n=4)$ dropped out of the cognitive orientation therapy. Further, $83 \%(n=5)$ of $\mathrm{AN}$ patients treated with self psychology therapy achieved remission compared to no patients in the cognitive orientation therapy. Of importance, the high rate of dropout in the latter treatment meant that only two AN participants completed that condition. Thus, results suggest self psychology may be possibly efficacious and specific for treating older adolescents with $\mathrm{AN}$, according to criteria presented by Chambless and Ollendick (2001).

In adolescent patients with $\mathrm{AN}$ or BN, Perpina et al. (1999) compared the efficacy of Cash's (1996) body image treatment coupled with either relaxation training or a virtual reality component. The virtual reality component included six body image exercises. For example, one exercise required the patient to manipulate a three-dimensional human figure until she believed its reflection in a virtual mirror matched her own dimensions. A second virtual mirror presented a translucent two-dimensional image of the patient's actual body. The patient then overlapped the two mirror images and adjusted the three-dimensional image until there was no discrepancy between them. Dropout rates were higher in the standard body image plus relaxation condition $(44 \% ; n=4)$ compared to the body image plus virtual reality condition $(11 \% ; n=1)$, although no statistically significant difference was reported between the small groups.

Among participants who completed treatment, results indicated superior improvements on measures of body image (but no significant differences on indexes of other eating disorder symptoms) for the virtual reality compared to the relaxation condition. Participants in both conditions demonstrated decreased scores on four measures: EAT, Restraint Scale, Bulimic Investigatory Test Edinburgh, and Eating Disorder Inventory. Thus, the virtual reality component for body image represents 
a possibly efficacious and specific treatment for body image disturbance, according to criteria presented by Chambless and Ollendick (2001).

In a study of inpatients with AN, Okamoto et al. (2002) compared different types of psychosocial intervention to facilitate refeeding adolescents with $\mathrm{AN}$. The first therapy, Fukamachi's activity restriction therapy (ART) used between 1988 and 1990, set an initial target weight and made engagement in entertaining activities contingent upon food intake. The second therapy, used between 1991 and 1992, combined ART with a token economy program in which patients were rewarded for weight gain with points that could be redeemed for entertaining activities. The third therapy, Kyoto Prefectural University of Medicine Behavior Therapy (KPT), which has been used since 1992, set no initial goal weight. Instead, psychoeducation was provided on the physical and mental consequences of starvation and benefits of weight restoration by liquid meal. No restrictions were placed on entertainments that could be employed while in bed. Thus, the first two treatments involved behavioral techniques to facilitate weight gain, whereas the third emphasized psychoeducation.

Patients treated with KPT demonstrated significantly greater increases in body mass index compared to patients treated with ART, whereas no significant differences were found between ART + token economy and KPT or ART treatment. It is important to note that the three treatments were accompanied by different nutritional approaches, and differential treatment outcomes may be because of cohort effects. That is, superior results achieved by the most recent form of therapy used (KPT) may be attributable to historical improvements in medical management of AN. Finally, patients receiving KPT had a mean age of 20.5 years, whereas patients receiving ART with and without a token economy had mean ages of 18.2 and 18.4 years, respectively. Although not statistically significant, age differences constrain conclusions regarding the superiority of the psychoeducational component to facilitate weight gain in adolescent inpatients with $\mathrm{AN}$.

\section{Studies in Adolescent Samples With BN}

Two recent studies (le Grange et al., 2007; Schmidt et al., 2007) have examined a version of the Maudsley model of family therapy modified for the treatment of BN and closely related EDNOS in adolescents. Le Grange et al. (2007) compared family therapy to supportive psychotherapy for younger adolescents ( $M$ age $=16$ years, range $=12-19$ years) who lived with their families. As with family therapy for AN, family therapy for BN included three phases: (a) empowering parents to disrupt disordered eating behaviors (e.g., binge eating and purging) and separating the disordered behaviors from the adolescent's self-identity, (b) transitioning control of eating from parents to adolescents, and (c) assisting the family in addressing the effects of BN on adolescent developmental processes (le Grange et al., 2007). Treatment included 20 sessions over 6 months.

As a credible comparison condition, supportive psychotherapy was adapted from a treatment utilized in adult outpatients with BN (Walsh et al., 1997). Duration and frequency of sessions were matched to that for family therapy. However, the treatment included "no putative active ingredients" and was designed to have no overlap with cognitive behavior, interpersonal, or analytic therapy. Instead, the first phase of treatment was designed to establish a strong therapeutic alliance and develop a detailed personal and family history and description of eating disorder development to help the patient identify underlying problems that might have contributed to the development of the eating disorder. The second phase delved further into underlying emotional problems and encouraged patients to express their feelings. Patients were responsible for introducing topics for discussion in the nondirective supportive psychotherapy condition, and this was intended to foster independence and prepare patients for termination. The third phase of treatment reviewed underlying issues and invited patients to examine the extent to which these issues continued to impact their lives and how they might address these issues in the future.

Treatment adherence was high in both conditions (patients attended $85 \%$ of sessions) and did not differ significantly between conditions. Results supported the superiority of family therapy compared to supportive psychotherapy in producing higher rates of remission at treatment end $(39 \%, n=16$ vs. $18 \%, n=7)$ and 6month follow-up $(29 \%, n=12$ vs. $10 \%, n=4)$. Similar improvements were observed for patients with $D S M-I V$ $\mathrm{BN}$ and patients with closely related EDNOS. Thus, results suggest that family therapy may be possibly efficacious and specific for treating younger adolescents with BN and related EDNOS, according to criteria presented by Chambless and Ollendick (2001). One concern with this study was that interview assessments of treatment response were not conducted blind to treatment condition (le Grange et al., 2007). Thus, this study cannot be classified as a Type I study.

Schmidt et al. (2007) utilized a randomized controlled trial (RCT) to compare family therapy and CBT guided self-care (or self-help) for older adolescents ( $M$ age $=17.5$ years, range $=13-20$ years) with $\mathrm{BN}$ and closely related EDNOS. The 6-month family therapy was similar to that used by le Grange et al. (2007) except that it involved fewer sessions (13 vs. 20 family sessions). CBT guided self-care was based on a self-help treatment 
developed for adult patients with BN (Schmidt \& Treasure, 1997). The treatment utilized a workbook for patients and close relatives/friends as well as a guide for therapists. Patients met with clinicians for 10 weekly sessions, received 3 monthly follow-up sessions, and were offered 2 optional sessions with a close relative/ friend. The therapist guided patients through the workbook and motivated patients to utilize the self-help treatment. The initial focus of CBT guided self-care was the function of the eating disorder in the patient's life. Self-monitoring of thoughts, feelings, and behaviors was used to reveal how bulimic symptoms were maintained. Problem-solving techniques and behavioral experiments were introduced to interrupt cycles of disordered behaviors. Homework was used throughout treatment. At the end of the 10-weekly sessions, the therapist wrote a "good-bye letter," and follow-up sessions were focused on relapse prevention.

Treatment adherence was somewhat lower in this study compared to adherence in the le Grange et al. (2007) study (see Table 1), despite a more lenient definition of adherence used by Schmidt et al. (2007; i.e., four or more sessions attended). Adherence did not differ significantly between the family therapy and CBT. No significant difference was found between the family therapy and CBT for rates of abstinence from binge-purge behaviors at treatment end $(12.5 \%, n=4$; and $19.4 \%, n=6$, respectively) or 12-month follow-up $(41.4 \%, n=12$; and $36.0 \%, n=9$, respectively). However, there was a significantly higher rate of abstinence from binge eating at treatment end in CBT $(41.9 \%$, $n=13)$ compared to family therapy $(25.0 \%, n=8)$ that was no longer evident at 12-month follow-up (52\%, $n=13$ in CBT vs. $55 \%, n=16$ in family therapy). Further, no significant differences were observed between treatment conditions for other indicators of disordered eating symptoms. Finally, CBT was associated with lower direct costs of treatment compared to family therapy (Schmidt et al., 2007).

Based on faster improvements in binge eating in CBT guided self-care, this treatment may be considered possibly efficacious and specific for treating binge eating in older adolescents with BN and related EDNOS, according to criteria presented by Chambless and Ollendick (2001). The limited superiority of CBT self-care to family therapy found by Schmidt et al. (2007) may reflect the use of two efficacious treatments for treating adolescents with BN. However, additional studies are needed to test this hypothesis. Based on the limited data that have been collected on the treatment of adolescents with BN, family therapy appears to be possibly efficacious and specific (le Grange et al., 2007), and CBT self-care appears to have at least similar efficacy to, and perhaps a slight advantage over, family therapy (Schmidt et al., 2007).

\section{Studies in Adult Samples}

Table 3 summarizes RCTs in adult samples in which there are at least 10 patients per treatment arm. These studies are briefly reviewed because many of them had an age range of 18 to 30 or 18 to 45 years yet included a high proportion of older adolescents (i.e., 18-21 years of age) given the preponderance of eating disorders in late adolescent/young adult women. Treatment condition(s) that were superior to alternate treatment conditions (including control conditions) across one or more outcome domains are listed under the column titled Treatments Associated With Best Outcomes. There are 50 articles included in this table, of which half have examined the efficacy of some form of CBT for the treatment of $\mathrm{BN}$. In adult samples, CBT represents a well-established intervention for the treatment of $\mathrm{BN}$ based on the APA Task Force (1995) criteria. CBT may represent an efficacious treatment for $\mathrm{BN}$ in older adolescents given evidence of its efficacy in late adolescent/young adult samples and preliminary findings in older adolescents reviewed earlier (Schmidt et al., 2007). CBT also represents a probably efficacious treatment for BED in adults. For AN, CBT was found to be superior to nutritional counseling in preventing relapse among weight-recovered patients (Pike, Walsh, Vitousek, Wilson, \& Bauer, 2003) but inferior to nonspecific individual therapy in the acute phase of AN (McIntosh et al., 2005). Interpersonal therapy (IPT) represents a probably efficacious treatment for BED but has been found to be inferior to CBT in the treatment of $\mathrm{BN}$. Finally, nonspecific individual therapy has been demonstrated to be superior to alternative treatments for AN in two studies (McIntosh et al., 2005; Russell et al., 1987). However, it is difficult to generalize results because nonspecific therapy, by its nature, does not represent a standardized, manual-based treatment. Thus, nonspecific individual therapy remains a possibly efficacious and specific treatment for adult AN patients.

Several studies have investigated the long-term impact of psychosocial treatments. For adult AN patients, nonspecific individual therapy continued to be superior to family therapy at 5-year follow-up (Eisler et al., 1997). In BN samples, CBT has been associated with maintenance of treatment gains over 6 months to 1-year follow-up (i.e., Agras, Rossiter, et al., 1994; Fairburn, Jones, Peveler, Hope, \& O'Connor, 1993), improved eating disorder outcome 5 to 9 years following treatment (Fairburn et al., 1995) and better social adjustment at 10-year follow-up (Keel, Mitchell, Davis, $\&$ Crow, 2002). However, the superiority of CBT compared to IPT has not been maintained at follow-up (Fairburn et al., 1993; Fairburn et al., 1995). For BED, CBT and IPT have been associated with sustained and similar improvements in binge eating at 1-year follow-up 
TABLE 3

Summary of Randomized Controlled Treatment Studies in Adult Samples

\begin{tabular}{|c|c|c|c|}
\hline Author & Age $M$ Range & Treatment Conditions $(N)$ & $\begin{array}{l}\text { Treatments Associated } \\
\text { With Best Outcomes }\end{array}$ \\
\hline \multicolumn{4}{|l|}{ Anorexia nervosa } \\
\hline \multirow[t]{4}{*}{ Crisp et al. (1991) } & 22 & Inpatient tx (30) & - Inpatient tx \\
\hline & $20-23$ & Outpatient ind/fam $\operatorname{tx}(20)$ & - Outpatient ind tx \\
\hline & & Outpatient group tx (20) & - Outpatient group tx \\
\hline & & No further tx $(20)$ & \\
\hline \multirow{4}{*}{$\begin{array}{l}\text { Dare, Eisler, Russell, } \\
\quad \text { Treasure, \& Dodge (2001) }\end{array}$} & 26.3 & Family therapy (22) & - Family therapy \\
\hline & & Focal psychoanalytic therapy (21) & - Focal psychoanalytic therapy \\
\hline & & Cognitive-analytic therapy (22) & \\
\hline & & Routine tx (19) & \\
\hline \multirow[t]{3}{*}{ McIntosh et al. (2005) } & $17-40$ & CBT (19) & - Nonspecific therapy \\
\hline & & IPT (21) & \\
\hline & & Nonspecific therapy (16) & \\
\hline \multirow{2}{*}{$\begin{array}{l}\text { Pike, Walsh, Vitousek, } \\
\text { Wilson, \& Bauer (2003) }\end{array}$} & 25.3 & CBT (18) & $\bullet \mathrm{CBT}$ \\
\hline & & Nutritional counseling (15) & \\
\hline \multirow{2}{*}{$\begin{array}{l}\text { Russell, Szmukler, Dare, \& } \\
\text { Eisler }(1987)^{b}\end{array}$} & 24.7 & Family therapy (17) & - Nonspecific individual therapy \\
\hline & & Nonspecific ind tx (16) & \\
\hline \multirow[t]{2}{*}{ Treasure et al. (1995) } & 25.02 & Cognitive analytical therapy (14) & - None \\
\hline & $18-39$ & Educational behavior therapy (16) & \\
\hline \multicolumn{4}{|l|}{ Bulimia nervosa } \\
\hline \multirow[t]{3}{*}{ Agras et al. (1992) } & 29.6 & CBT (23) & - CBT + Desipramine \\
\hline & & Desipramine (24) & \\
\hline & & CBT + Desipramine (24) & \\
\hline \multirow{4}{*}{$\begin{array}{l}\text { Agras, Schneider, Arnow, } \\
\text { Raeburn, \& Telch (1989) }\end{array}$} & 29.2 & Self-monitoring group (19) & $\bullet \mathrm{CBT}$ \\
\hline & $18-61$ & CBT (22) & \\
\hline & & ERP (17) & \\
\hline & & Waitlist (19) & \\
\hline \multirow{2}{*}{$\begin{array}{l}\text { Agras, Walsh, Fairburn, } \\
\text { Wilson, \& Kraemer (2000) }\end{array}$} & 28.1 & CBT (110) & - $\mathrm{CBT}$ \\
\hline & & IPT (110) & \\
\hline \multirow{3}{*}{$\begin{array}{l}\text { Bulik, Sullivan, Carter, } \\
\text { McIntosh, \& Joyce (1998) }\end{array}$} & 26.1 & CBT + ERP-binge cues (37) & - $\mathrm{CBT}+$ ERP-binge cues \\
\hline & & CBT + ERP-purge cues (35) & \\
\hline & & $\mathrm{CBT}+$ relaxation training (39) & \\
\hline \multirow{3}{*}{ Carter et al. (2003) } & 27 & CBT self-help (28) & - CBT self-help \\
\hline & $17-53$ & Nonspecific self-help (28) & - Nonspecific self-help \\
\hline & & Waitlist (29) & \\
\hline \multirow[t]{2}{*}{ Chen et al. (2003) } & 25.8 & Group CBT (30) & - Ind CBT \\
\hline & & Ind CBT (30) & \\
\hline \multirow[t]{2}{*}{ Cooper \& Steere (1995) } & 23.8 & CBT (15) & - None \\
\hline & $18-33$ & ERP (16) & \\
\hline \multirow{2}{*}{$\begin{array}{l}\text { Davis, McVey, Heinmaa, } \\
\text { Rockert, \& Kennedy (1999) }\end{array}$} & 27.1 & $\mathrm{PE}+\mathrm{CBT}(39)$ & - $\mathrm{PE}+\mathrm{CBT}$ \\
\hline & $18-41$ & PE (19) & \\
\hline \multirow{2}{*}{$\begin{array}{l}\text { Esplen, Garfinkel, Olmstead, } \\
\text { Gallop \& Kennedy (1998) }\end{array}$} & 26.6 & Guided imagery (28) & - Guided imagery \\
\hline & & Control group (30) & \\
\hline \multirow[t]{3}{*}{ Fairburn et al. $(1991)^{a}$} & 24.2 & CBT (25) & - $\mathrm{CBT}$ \\
\hline & & IPT (25) & \\
\hline & & BT (25) & \\
\hline \multirow{2}{*}{$\begin{array}{l}\text { Fairburn, Kirk, O'Connor, \& } \\
\quad \text { Cooper }(1986)^{a}\end{array}$} & 22.9 & CBT (12) & - $\mathrm{CBT}$ \\
\hline & & $\begin{array}{l}\text { Short-term focal } \\
\text { psychotherapy (12) }\end{array}$ & \\
\hline Freeman, Barry, & 24.2 & CBT (32) & • BT \\
\hline Dunkeld-Turnbull, \& & $18-42$ & BT (30) & \\
\hline Henderson $(1988)^{a}$ & & Group (30) & \\
\hline & & Waitlist (20) & \\
\hline Garner et al. (1993) & 24.2 & CBT (30) & - $\mathrm{CBT}$ \\
\hline & & $\begin{array}{l}\text { Supportive-expressive } \\
\text { therapy (30) }\end{array}$ & \\
\hline Goldbloom et al. (1997) ${ }^{a}$ & 25.8 & CBT (24) & - $\mathrm{CBT}$ \\
\hline & & CBT + Fluoxetine (29) & - $\mathrm{CBT}+$ Fluoxetine \\
\hline & & Fluoxetine (23) & \\
\hline
\end{tabular}


TABLE 3

Continued

\begin{tabular}{|c|c|c|c|}
\hline Author & Age $M$ Range & Treatment Conditions (N) & $\begin{array}{l}\text { Treatments Associated } \\
\text { With Best Outcomes }\end{array}$ \\
\hline $\begin{array}{l}\text { Griffiths, Hadzi-Pavlovic, \& } \\
\text { Channon-Little (1994) }\end{array}$ & 25.91 & $\begin{array}{l}\text { CBT (23) } \\
\text { Hypnobehavioral tx (27) } \\
\text { Waitlist (28) }\end{array}$ & $\begin{array}{l}\text { - CBT } \\
\text { - Hypnobehavioral tx }\end{array}$ \\
\hline Huon \& Brown (1985) & $\begin{array}{l}25.8 \\
18-42\end{array}$ & $\begin{array}{l}\text { Eclectic group tx } 12 \mathrm{wk}(10) \\
\text { Waitlist } 12 \mathrm{wk}+\text { eclectic } \\
\text { group tx } 12 \mathrm{wk}(10) \\
\text { Waitlist } 6 \mathrm{wk} \\
\quad+\text { Intensive eclectic group } \\
\text { tx } 12 \mathrm{wk}(20)\end{array}$ & - Eclectic group tx \\
\hline $\begin{array}{l}\text { Jacobi, Dahme, \& } \\
\text { Dittmann (2002) }\end{array}$ & 26 & $\begin{array}{l}\text { CBT (19) } \\
\text { Fluoxetine (16) } \\
\text { Combined (18) }\end{array}$ & - None \\
\hline $\begin{array}{l}\text { Kirkley, Schneider, Agras, \& } \\
\text { Bachman }(1985)^{a}\end{array}$ & $\begin{array}{r}28.3 \\
18-46\end{array}$ & $\begin{array}{l}\text { CBT (14) } \\
\text { Nondirective (14) }\end{array}$ & - CBT \\
\hline Laessle et al. (1991) & 23.8 & $\begin{array}{l}\text { Nutritional management (27) } \\
\text { Stress management (28) }\end{array}$ & - Nutritional management \\
\hline Lee \& Rush (1986) & 27.7 & $\begin{array}{l}\text { CBT (15) } \\
\text { Waitlist (15) }\end{array}$ & - CBT \\
\hline $\begin{array}{l}\text { Leitenberg, Rosen, Gross, } \\
\text { Nudelman, \& Vara (1987) }\end{array}$ & 26 & $\begin{array}{l}\text { ERP: Multiple setting (12) } \\
\text { ERP: Single setting (11) } \\
\text { No-exposure CBT (12) } \\
\text { Waitlist (12) }\end{array}$ & - ERP \\
\hline Mitchell et al. (1990) & 23.9 & $\begin{array}{l}\text { Imipramine (54) } \\
\text { Group therapy + Imipramine }(52) \\
\text { Group therapy + placebo (34) } \\
\text { Placebo (31) }\end{array}$ & $\begin{array}{l}\text { - Group therapy + Imipramine } \\
\text { - Group therapy + placebo }\end{array}$ \\
\hline Mitchell et al. (1993) & 25.9 & $\begin{array}{l}\text { CBT group: high intensity, } \\
\text { high emphasis on abstinence } \\
\text { (33) } \\
\text { CBT group: low intensity, high } \\
\text { emphasis on abstinence (41) } \\
\text { CBT group: high intensity, low } \\
\text { emphasis on abstinence (35) } \\
\text { CBT group: low intensity, low } \\
\text { emphasis on abstinence (34) }\end{array}$ & $\begin{array}{l}\text { - CBT group: high intensity, } \\
\text { high emphasis on abstinence } \\
\text { - CBT group: low intensity, } \\
\text { high emphasis on abstinence } \\
\text { - CBT group: high intensity, } \\
\text { low emphasis on abstinence }\end{array}$ \\
\hline $\begin{array}{l}\text { Ordman \& Kirschenbaum } \\
\text { (1985) }\end{array}$ & $\begin{array}{c}19.8 \\
18-30\end{array}$ & $\begin{array}{l}\text { Full-intervention (10) } \\
\text { Brief-intervention (10) }\end{array}$ & - Full intervention \\
\hline $\begin{array}{l}\text { Palmer, Birchall, McGrain, \& } \\
\text { Sullivan }(2002)^{c}\end{array}$ & 26.9 & $\begin{array}{l}\text { Self-help w/ minimal guidance (32) } \\
\text { Self-help w/ face-to-face } \\
\quad \text { guidance (30) } \\
\text { Self-help w/ telephone } \\
\quad \text { guidance (28) } \\
\text { Waitlist (31) }\end{array}$ & $\begin{array}{l}\text { - Self-help w/ face-to-face } \\
\text { guidance }\end{array}$ \\
\hline $\begin{array}{l}\text { Russell, Szmukler, Dare, \& } \\
\text { Eisler }(1987)^{b}\end{array}$ & 24 & $\begin{array}{l}\text { Family therapy (10) } \\
\text { Nonspecific ind tx (10) }\end{array}$ & - None \\
\hline Safer, Telch, \& Agras (2001) & $\begin{array}{r}34 \\
18-54\end{array}$ & $\begin{array}{l}\text { DBT (16) } \\
\text { Waitlist (15) }\end{array}$ & $\bullet$ DBT \\
\hline $\begin{array}{l}\text { Thackwray, Smith, Bodfish, \& } \\
\text { Meyers (1993) }\end{array}$ & $\begin{array}{r}31.3 \\
15-62\end{array}$ & $\begin{array}{l}\text { (Total } N=47) \\
\text { CBT } \\
\text { BT } \\
\text { Nonspecific self-monitoring }\end{array}$ & $\begin{array}{l}-\mathrm{CBT} \\
\bullet \mathrm{BT}\end{array}$ \\
\hline Treasure et al. (1999) & 28.7 & $\begin{array}{l}\text { Motivational enhancement } \\
\text { Therapy ( } 87 \text { ) } \\
\text { Ind CBT (38) }\end{array}$ & - None \\
\hline Treasure et al. (1994) & 25.8 & $\begin{array}{l}\text { CBT (21) } \\
\text { CBT self-help manual (41) } \\
\text { Waitlist (19) }\end{array}$ & $\begin{array}{l}\text { - CBT } \\
\text { - CBT self-help manual }\end{array}$ \\
\hline Treasure et al. (1996) & 25.8 & $\begin{array}{l}\text { 16-wk CBT (55) } \\
\text { CBT-SH: Sequential } \\
\text { 8-wk self-care manual } \\
\text { + 8-wk CBT (55) }\end{array}$ & - None \\
\hline
\end{tabular}


TABLE 3

Continued

\begin{tabular}{|c|c|c|c|}
\hline Author & Age M Range & Treatment Conditions $(N)$ & $\begin{array}{l}\text { Treatments Associated } \\
\text { With Best Outcomes }\end{array}$ \\
\hline Walsh et al. (1997) & $\begin{array}{r}26.1 \\
18-39\end{array}$ & $\begin{array}{l}\text { CBT }+ \text { medication }(23) \\
\text { CBT }+ \text { placebo }(25) \\
\text { Supportive } t x+\text { medication }(22) \\
\text { Supportive } t x+\text { placebo }(22) \\
\text { Medication }(28)\end{array}$ & - $\mathrm{CBT}+$ medication \\
\hline $\begin{array}{l}\text { Wilson, Eldredge, Smith, \& } \\
\text { Niles (1991) }\end{array}$ & 20.7 & $\begin{array}{l}\text { CBT }(11) \\
\text { CBT }+ \text { ERP }(11)\end{array}$ & - None \\
\hline Wolf \& Crowther (1992) & 26 & $\begin{array}{l}\text { CBT (15) } \\
\text { BT (15) } \\
\text { Waitlist (11) }\end{array}$ & $\begin{array}{l}\bullet \mathrm{CBT} \\
\bullet \mathrm{BT}\end{array}$ \\
\hline \multicolumn{4}{|l|}{ Binge Eating Disorder } \\
\hline Agras et al. (1995) & $\begin{aligned} & 47.6 \\
24-65 & \end{aligned}$ & $\begin{array}{l}\text { CBT (39) } \\
\text { Waitlist (11) }\end{array}$ & $\bullet \mathrm{CBT}$ \\
\hline Agras, Telch, et al. (1994) & $\begin{array}{r}45 \\
22-65\end{array}$ & $\begin{array}{l}\text { WT: weight loss tx (37) } \\
\text { CBT + WT (36) } \\
\text { CBT + WT + Desipramine (35) }\end{array}$ & - None \\
\hline Carter \& Fairburn $(1998)^{a}$ & $\begin{array}{r}39.7 \\
21-59\end{array}$ & $\begin{array}{l}\text { CBT: Pure self-help (35) } \\
\text { CBT: Guided self-help (34) } \\
\text { Waitlist (24) }\end{array}$ & - CBT: Guided self-help \\
\hline Gorin, le Grange, \& Stone (2003) & 45.20 & $\begin{array}{l}\text { Group CBT (32) } \\
\text { Group CBT w/ spousal } \\
\quad \text { involvement (31) } \\
\text { Waitlist (31) }\end{array}$ & $\begin{array}{l}\text { - Group CBT } \\
\text { - Group CBT w/ spousal } \\
\text { involvement }\end{array}$ \\
\hline Levine, Marcus, \& Moulton (1996) & 36.6 & $\begin{array}{l}\text { Tx exercise program for BED (44) } \\
\text { Delayed tx control (33) }\end{array}$ & - Tx exercise program \\
\hline Peterson et al. (1998) & $\begin{array}{l}42.4 \\
18-65\end{array}$ & $\begin{array}{l}\text { Therapist-led CBT (16) } \\
\text { Partial self-help CBT (19) } \\
\text { Structured self-help CBT (15) } \\
\text { Waitlist (11) }\end{array}$ & $\begin{array}{l}\text { - Therapist-led CBT } \\
\text { - Partial self-help CBT } \\
\text { - Structured self-help CBT }\end{array}$ \\
\hline Telch, Agras, \& Linehan (2001) & 50 & $\begin{array}{l}\text { DBT (22) } \\
\text { Waitlist (22) }\end{array}$ & $\bullet$ DBT \\
\hline $\begin{array}{l}\text { Telch, Agras, } \\
\text { Rossiter, Wilfley, \& } \\
\text { Kenardy (1990) }\end{array}$ & $\begin{aligned} & 42.6 \\
& 25-61\end{aligned}$ & $\begin{array}{l}\text { Group CBT (23) } \\
\text { Waitlist (21) }\end{array}$ & $\bullet \mathrm{CBT}$ \\
\hline Wilfley et al. (1993) & $\begin{array}{r}44.3 \\
27-64\end{array}$ & $\begin{array}{l}\text { Group CBT (18) } \\
\text { Group IPT (18) } \\
\text { Waitlist (20) }\end{array}$ & $\begin{array}{l}\bullet \mathrm{CBT} \\
\bullet \mathrm{IPT}\end{array}$ \\
\hline Wilfley et al. (2002) ${ }^{a}$ & 45.3 & $\begin{array}{l}\text { Group CBT (81) } \\
\text { Group IPT (81) }\end{array}$ & - None \\
\hline
\end{tabular}

Note: $\mathrm{tx}=$ treatment; ind $=$ individual; $\mathrm{fam}=$ family; $\mathrm{CBT}=$ cognitive behavioral therapy; $\mathrm{ERP}=$ exposure plus response prevention; $\mathrm{IPT}=$ interpersonal psychotherapy; $\mathrm{PE}=$ psychoeducational treatment; $\mathrm{BT}=$ behavioral therapy; wk $=$ week; DBT $=$ dialectical behavioral therapy; $\mathrm{SH}=$ self help; $\mathrm{WT}=$ weight loss treatment; $\mathrm{BED}=$ binge eating disorder.

${ }^{a}$ Random assignment to condition utilized blocked, stratified, restricted randomization or assignment to group with greatest mean difference from participant to avoid significant pretreatment differences among groups.

${ }^{b}$ Russell et al. (1987) consisted of three groups: bulimia nervosa (BN), adult anorexia nervosa, and adolescent anorexia nervosa (see Table 1).

${ }^{c}$ Palmer et al. (2002) included BN $(n=71)$, BED $(n=28)$, and eating disorder not otherwise specified-partial BN $(n=22)$.

(Wilfley et al., 1993; Wilfley et al., 2002). Thus, psychosocial treatments are effective at producing long-term change in adult samples.

\section{IMPLICATIONS AND CONCLUSIONS}

Family therapy represents a well-established intervention for the treatment of $\mathrm{AN}$ in adolescents (see Table 4). In addition, family therapy has demonstrated superiority to an alternative treatment (supportive psychotherapy) in one RCT for $\mathrm{BN}$ in adolescents (le Grange et al., 2007), suggesting that it is a possibly efficacious treatment with specific effects. In addition, a second study indicated that a form of CBT may be superior to family therapy in adolescent patients with $\mathrm{BN}$ in reduction of binge-eating behavior (Schmidt et al., 2007). However, no other differences emerged between CBT guided self-care and family therapy in this study of older adolescents (Schmidt et al., 2007). 
TABLE 4

Evidence-Based Psychosocial Interventions for Eating Disorders in Adolescence

\begin{tabular}{ll}
\hline Treatment & Citation for Efficacy Evidence \\
\hline Well-Established Treatments ${ }^{a}$ & \\
Family Therapy for AN & $\begin{array}{l}\text { Russell et al. (1987) } \\
\text { Robin et al. (1999) }\end{array}$ \\
Probably Efficacious Treatments & None \\
None & \\
Possibly Efficacious and Specific Treatments & Bachar et al. (1999) \\
Psychoanalytic Therapy (Self Psychology) for AN & Perpina et al. (1999) \\
Cash's Body Image Therapy + Virtual Reality for AN & Le Grange et al. (2007) \\
Family Therapy for BN & Schmidt et al. (2007) \\
CBT Guided Self-Care for Binge Eating in BN & \\
\hline \multicolumn{2}{l}{ Note: AN = Anorexia nervosa. } \\
${ }^{a}$ There are no well-established psychosocial treatments for adolescents with bulimia nervosa (BN). However, cognitive beha- \\
vioral therapy (CBT) represents a well-established treatment for older adolescents/young adults with BN (Cooper \& Steere, \\
1985; Fairburn et al., 1991; Fairburn, Kirk, O'Connor, \& Cooper, 1986; Garner et al., 1993).
\end{tabular}

Of note, several of the adult randomized controlled trials presented in Table 3 included a preponderance of participants between the ages of 18 and 21 years, given that $\mathrm{BN}$ predominantly affects late adolescent and young adult females. Based on these investigations, CBT represents a well-established treatment for $\mathrm{BN}$ for late adolescent/young adult females.

Limited conclusions can be drawn regarding the efficacy of psychosocial treatments for eating disorders in children and adolescents because of several methodological aspects of the extant literature. First among these limitations is the dearth of controlled treatment studies in child or adolescent samples. Additional limitations include small samples, exclusion of male patients from many treatment studies, and limited ethnic and racial diversity of patient samples.

Most controlled treatment studies in eating disorders have examined interventions designed for $\mathrm{BN}$ in late adolescent/young adult samples. Although the limited number of studies on BED reflects its relatively recent recognition and the limited epidemiological data concerning its prevalence in children and adolescents (American Psychiatric Association, 1994), the same explanations cannot be given for AN. Instead, the small number of studies on AN in adolescents (or any age group) reflects in part the uniquely difficult aspects of treating patients who suffer from a dangerous and often ego-syntonic disorder. Waitlist control conditions do not represent an ethical option for most AN treatment studies. Thus, treatments have limited opportunity to appear "probably efficacious" on their way to becoming "well established." In addition, the ego-syntonic nature of AN makes obtaining informed consent and maintaining study participation challenging (Halmi et al., 2005). That is, many patients with AN do not perceive themselves as being ill and thus do not wish to receive treatment. It is important to note that Russell et al. (1987) found family treatment was superior to nonspecific individual therapy in adolescent patients but not adult patients with AN. These results suggest that caution must be used in extrapolating results from studies of adults to adolescent patients with eating disorders. Similarly, although CBT has emerged as a well-established treatment for adults with $\mathrm{BN}$, parallel data are lacking for adults with AN, suggesting that caution must be used in extrapolating results for one eating disorder to other eating disorders.

Although there are few controlled studies of young adolescents (e.g., younger than 15 years), there are no controlled treatment studies of children with eating disorders. One problem in evaluating treatment efficacy in children is the low base rate of $D S M-I V$ AN and $\mathrm{BN}$ in children. In the DSM-III-R (American Psychiatric Association, 1987), eating disorders were included within the section on disorders usually first evident in infancy, childhood, or adolescence. However, current eating disorder definitions in the DSM and ICD fail to capture the majority of eating disorders that appear in children (Nicholls, Chater, \& Lask, 2000). Much of this is because of the restriction of eating disorder "types" to those that occur predominantly in late adolescent/ young adult women. Thus, many diagnostic criteria are either inappropriate for prepubescent children, such as secondary amenorrhea, or difficult to assess in children, such as the undue influence of weight or shape on self-evaluation. Nicholls et al. recommended expansion of the classification to include syndromes that may be unique to children. These conditions include Food Avoidance Emotional Disorder, Selective Eating, Functional Dysphagia, and Pervasive Refusal Syndrome. To our knowledge, there have been no controlled treatment studies of these conditions.

Many controlled treatment studies exclude males from participation, and males represent a small proportion of 
patients in remaining studies (see Table 1). In contrast to their representation in controlled eating disorder treatment studies, males comprise 10 to $15 \%$ of individuals who suffer from eating disorders (American Psychiatric Association, 2000), with some evidence that the male-to-female ratio may be higher in children (Nicholls et al., 2000). However, the lower base rate of eating disorders in males makes it difficult to recruit adequate numbers to establish gender differences in treatment efficacy. Because eating disorder interventions have been designed, refined, and tested predominantly in females, it remains unclear whether these treatments are useful in treating boys with eating disorders.

Most controlled treatment studies in adolescents provide no information concerning the ethnic/racial diversity of study participants. In the studies that do describe ethnic/racial background of participants, ethnic minority representation appears to be a function of the geographic locations in which research has been conducted, and analyses of differential treatment completion or response are not presented. Thus, the question of whether ethnicity/race serves as a moderator variable cannot be answered.

\section{MODERATORS OF TREATMENT EFFECT}

Moderators of treatment outcome are factors that are independent of treatment condition but significantly influence the differential effects of treatment conditions (Kraemer, Wilson, Fairburn, \& Agras, 2002). As previously described, the limited diversity of patient samples makes it impossible to evaluate most demographic variables as possible moderators of treatment response. Similarly, no studies have examined therapist characteristics, such as age, gender, training background or experience, as possible moderators of treatment effect.

To our knowledge, only one study in adolescents has examined possible moderators of treatment response (Lock et al., 2005). Potential moderators here included age, session attendance, baseline body mass index, comorbidity, duration of illness, EDE (Fairburn \& Cooper, 1993) restraint subscale score, gender, intact family, principal investigator as therapist, purging status, medication use, hospitalization, Yale-BrownCornell Eating Disorder Scale (YBC-ED; Mazure, Halmi, \& Einhorn, 1995) total score, internalizing score on the Youth Self-Report and Child Behavior Checklist (Achenbach, 1991), and family income. Of these variables, only two demonstrated a significant interaction with treatment condition for 1-year outcome. First, higher YBC-ED scores, indicative of greater food and body obsessions/compulsions, were associated with greater weight gain in the long-term family therapy condition compared to the short-term family therapy condition. Second, patients from nonintact families demonstrated greater decreases in global EDE scores in the long-term versus short-term condition. No other significant moderators of treatment were identified in this study. As noted previously, Eisler et al. (2000) found that families characterized by high levels of expressed emotion (EE) responded less favorably to conjoint family therapy compared to those with low levels of EE, whereas no significant difference was found between high and low EE families in response to separated family therapy. Thus, known moderator variables remain elusive at present.

\section{MEDIATORS OF TREATMENT EFFECT}

Mediators of treatment outcome are not independent of treatment condition. Instead, they are a consequence of treatment that explain why one treatment is associated with improved outcomes compared to another (Kraemer et al., 2002). To our knowledge, no treatment study in an adolescent sample has examined mediators of treatment effects.

Studies of mediators in adult BN samples have produced conflicting results. Wilson, Fairburn, Agras, Walsh, and Kraemer (2002) found that reductions in dietary restraint and increases in self-efficacy to resist binge eating in response to eating cues partially mediated the effects of CBT on reductions in binge eating and purging. In addition, improvements in purging were mediated by increases in self-efficacy in response to negative affect and shape/weight cues. Interpersonal variables did not demonstrate significant mediation of treatment effects. In contrast, Spangler, Baldwin, and Agras (2004) found that engagement in treatment mediated the effects of relational interventions on reduced vomiting frequency. Neither dietary restriction nor body-related beliefs mediated the influence of CBT on symptom reduction. As noted previously, the relevance of findings from adult patients for treatment of adolescent patients is unknown.

\section{RECOMMENDATIONS FOR BEST PRACTICE}

For adolescent patients with AN, a family-based intervention has demonstrated superiority to an eclectic individual therapy (Russell et al., 1987) and psychoanalytically oriented individual therapy (Robin et al., 1999). Of note, it is not clear whether this treatment would be appropriate for older adolescent patients with AN who may live away from home. In addition, there is evidence that conjoint family therapy is somewhat preferable to separated family therapy. However, this evidence is inconsistent and separated family therapy may be 
superior for cases with high levels of maternal criticism (Eisler et al., 2000). There is some support for a self psychology therapy (Bachar et al., 1999) and body image therapy with a virtual reality component (Perpina et al., 1999) for AN in older adolescents. However, sample sizes were small in these studies, effect sizes could not be calculated for these treatments, and replication is lacking.

For an adolescent patient with $\mathrm{BN}$, it is unclear whether a family-based therapy or CBT guided self-care would be the preferred course of treatment because of limited controlled treatment studies in adolescent patients with $\mathrm{BN}$. Results from randomized controlled trials in adult samples (see Table 3 ) indicate that CBT is the treatment of choice for older adolescents (ages 18-21 years) with $\mathrm{BN}$, and results from a single RCT of older adolescents with BN comparing a form of CBT to family therapy indicate that CBT guided self care was associated with lower costs, similar benefits for most outcome measures, and superior results for posttreatment bingeeating abstinence. However, results from these studies may or may not generalize to younger adolescent patients with $\mathrm{BN}$ seen in a clinical setting.

As previously noted, there have been no controlled treatment studies of binge eating disorder in children or adolescents. Results from adult patients suggest that CBT or IPT may be useful, but it is not known whether similar findings would emerge in young patients. Finally, there have been no controlled treatment studies of conditions that may uniquely characterize disorders of eating in children such as Food Avoidance Emotional Disorder, Selective Eating, Functional Dysphagia, or Pervasive Refusal Syndrome.

\section{FUTURE DIRECTIONS}

Recommended future directions flow logically from the discussion of limitations in the current literature. Future studies of treatment in eating disorders would benefit from examining treatments in child and young adolescent populations, increasing the ethnic and racial diversity of patient groups, including greater numbers of male patients, and investigating treatments for the full range of eating disorders that occur in children and adolescents.

Few studies examine the efficacy of treatments for individuals who fall beyond the narrow diagnostic criteria set by various editions of the DSM. Of interest, the majority of adolescents who suffer from clinically significant eating disorders do not fall within the narrow diagnostic categories defined by the DSM (Leon et al., 1999). This fact is likely to explain the small number of studies of younger patients as well as the small sample sizes in the few studies of adolescent patients that exist.
Thus, the adage that "we study what we define" (Walsh \& Kahn, 1997, p. 369) may have a particularly deleterious effect on developing evidence-based treatments for eating disorders in children and adolescents.

A new transdiagnostic approach to the treatment of eating disorders has been proposed to expand the use of CBT to individuals who suffer from clinically significant eating disorders, regardless of their specific symptom profiles (Fairburn, 2002). However, it is unclear whether proponents of the transdiagnostic approach would advocate for the use of CBT across different age groups. Given minimal support for the efficacy of CBT for adults with AN or for children with any eating disorder, it will be important for researchers to track treatment response for groups with different symptom profiles as well as for different age groups.

Finally, greater effort is needed in the field to improve the quality of treatment studies conducted in child and adolescent patients with eating disorders. Only two of the studies listed in Table 1 (Lock et al., 2005; Schmidt et al., 2007) were classified as a Type 1 study according to the criteria used by Nathan and Gorman (2002). Beyond small sample sizes, other studies have been hampered by the use of nonmanualized treatments, less than state-of-the art diagnostic methods, poor description of inclusion/exclusion criteria, and incomplete reporting of data and analyses.

In conclusion, the evidence-base for psychosocial treatments for eating problems in children and adolescents is quite limited at this time. As a consequence of the small number of studies and methodological limitations in existing studies, it is not possible to describe what treatments work for whom for most cases. Based on their efficacy in treating AN in adolescent patients, family-based approaches represent a promising avenue for future treatment studies of other eating problems in children and adolescents.

\section{REFERENCES}

Achenbach, T. (1991). Manual for the child-behavior checklist/4-18 and 1991 profile. Burlington: University of Vermont.

Agras, W. S., Rossiter, E. M., Arnow, B., Schneider, J. A., Telch, C. F., Raeburn, S. D., et.al. (1992). Pharmacologic and cognitivebehavioral treatment for bulimia nervosa: A controlled comparison. American Journal of Psychiatry, 149, 82-87.

Agras, W. S., Rossiter, E. M., Arnow, B., Telch, C. F., Raeburn, S., Bruce, B., et al. (1994). One-year follow-up of psychosocial and pharmacologic treatments for bulimia nervosa. Journal of Clinical Psychiatry, 55, 179-183.

Agras, W. S., Schneider, J. A., Arnow, B., Raeburn, S., \& Telch, C. F. (1989). Cognitive-behavioral and response-prevention treatments for bulimia nervosa. Journal of Consulting and Clinical Psychology, 57, 215-221.

Agras, W. S., Telch, C. F., Arnow, B., Eldredge, K., Detzer, M. J., Henderson, J., et al. (1995). Does interpersonal therapy help patients 
with binge eating disorder who fail to respond to cognitivebehavioral therapy? Journal of Consulting and Clinical Psychology, 63, 356-360.

Agras, W. S., Telch, C. F., Arnow, B., Eldredge, K., Wilfley, D. E., Raeburn, S. D., et al. (1994). Weight loss, cognitive-behavioral, and desipramine treatments in binge eating disorder: An additive design. Behavior Therapy, 25, 225-238.

Agras, W. S., Walsh, B. T., Fairburn, C. G., Wilson, G. T., \& Kraemer, H. C. (2000). A multicenter comparison of cognitivebehavioral therapy and interpersonal therapy for bulimia nervosa. Archives of General Psychiatry, 57, 459-466.

American Psychiatric Association. (1987). Diagnostic and statistical manual of mental disorders, third edition revised (DSM-III-R). Washington, DC: American Psychiatric Association.

American Psychiatric Association. (1994). Diagnostic and statistical manual of mental disorders, fourth edition (DSM-IV). Washington, DC: American Psychiatric Association.

American Psychiatric Association. (2000). Diagnostic and statistical manual of mental disorders, fourth edition text revision (DSM-IV$T R)$. Washington, DC: American Psychiatric Association.

APA Task Force on Promotion and Dissemination of Psychological Procedures, Division of Clinical Psychology (1995). Training in and dissemination of empirically-validated psychological treatments: Report and recommendations. Clinical Psychologist, 48, 3-23.

Bachar, E., Latzer, Y., Kreitler, S., \& Berry, E.M. (1999). Empirical comparison of two psychological therapies: Self psychology and cognitive orientation in the treatment of anorexia and bulimia. Journal of Psychotherapy Practice and Research, 8, 115-128.

Bulik, C. M., Sullivan, P. F., Carter, F. A., McIntosh, V. V., \& Joyce, P. R. (1998). The role of exposure with response prevention in the cognitive-behavioural therapy for bulimia nervosa. Psychological Medicine, 28, 611-623.

Carter, J. C., \& Fairburn, C. G. (1998). Cognitive-behavioral self-help for binge eating disorder: A controlled effectiveness study. Journal of Consulting and Clinical Psychology, 66, 616-623.

Carter, J. C., Olmstead, M. P., Kaplan, A. S., McCabe, R. E., Mills, J. S., \& Aime, A. (2003). Self-help for bulimia nervosa: A randomized controlled trial. American Journal of Psychiatry, 160, 973-978.

Cash, T. F. (1996). The treatment of body image disturbances. In J. K. Thompson (Ed.), Body image, eating disorders and obesity (pp. 83-107). Washington, DC: American Psychological Association.

Chambless, D. L. \& Ollendick, T. H. (2001). Empirically supported psychological interventions: Controversies and evidence. Annual Review of Psychology, 52, 685-716.

Chen, E., Touyz, S. W., Beumont, P. J. V., Fairburn, C. G., Griffiths, R., Butow, P., et al. (2003). Comparison of group and individual cognitive-behavioral therapy for patients with bulimia nervosa. International Journal of Eating Disorders, 33, 241-254.

Cooper, P. J. \& Steere, J. (1995). A comparison of two psychological treatments for bulimia nervosa: implications for models of maintenance. Behaviour Research and Therapy, 33, 875-885.

Crisp, A. H., Norton, K., Gowers, S., Halek, C., Bowyer, C., Yeldham, D., et al. (1991). A controlled study of the effect of therapies aimed at adolescent and family psychopathology in anorexia nervosa. British Journal of Psychiatry, 159, 325-333.

Dare, C., Eisler, I., Russell, G. F., \& Szmukler, G. I. (1990). The clinical and theoretical impact of a controlled trial of family therapy in anorexia nervosa. Journal of Marital and Family Therapy, 16, 39-57.

Dare, C., Eisler, I., Russell, G., Treasure, J., \& Dodge, L. (2001). Psychological therapies for adults with anorexia nervosa: Randomized controlled trial of out-patient treatments. British Journal of Psychiatry, 178, 216-221.

Davis, R., McVey, G., Heinmaa, M., Rockert, W., \& Kennedy, S. (1999). Sequencing of cognitive-behavioral treatments for bulimia nervosa. International Journal of Eating Disorders, 25, 361-374.
Eisler, I., Dare, C., Hodes, M., Russell, G., Dodge, E., \& le Grange, D. (2000). Family therapy for adolescent anorexia nervosa: The results of a controlled comparison of two family interventions. Journal of Child Psychology and Psychiatry and Allied Disciplines, 41, 727-736.

Eisler, I., Dare, C., Russell, G. F., Szmukler, G., le Grange, D., \& Dodge, E. (1997). Family and individual therapy in anorexia nervosa: A 5-year follow-up. Archives of General Psychiatry, 54, $1025-1030$.

Eisler, I., Simic, M., Russell, G. F. M., \& Dare, C. (2007). A randomized controlled treatment trial of two forms of family therapy in adolescent anorexia nervosa: A 5-year follow-up. Journal of Child Psychology and Psychiatry, 48, 552-560.

Esplen, M. J., Garfinkel, P. E., Olmstead, M., Gallop, R. M., \& Kennedy, S. (1998). A randomized controlled trial of guided imagery in bulimia nervosa. Psychological Medicine, 28, 1347-1357.

Fairburn, C. G. (Novermber, 2002). "Transdiagnostic" research in eating disorders. New Treatment Studies Plenary presented at the Eating Disorder Research Society Meeting, Charlston, South Carolina.

Fairburn, C., \& Cooper, Z. (1993). The Eating Disorder Examination (12th ed.). In C. Fairburn \& G. T. Wilson (Eds.), Binge eating: Nature, assessment and treatment (pp. 317-331). New York: Guilford.

Fairburn, C. G., Jones, R., Peveler, R. C., Carr, S. J., Solomon, R. A., O'Connor, M. E., et al. (1991). Three psychological treatments for bulimia nervosa: A comparative trial. Archives of General Psychiatry, 48, 463-469.

Fairburn, C. G., Jones, R., Peveler, R. C., Hope, R. A., \& O’Connor, M. E. (1993). Psychotherapy and bulimia nervosa: The longer-term effects of interpersonal psychotherapy, behaviour therapy and cognitive behaviour therapy. Archives of General Psychiatry, 50, 419-428.

Fairburn, C. G., Kirk, J., O'Connor, M., \& Cooper, P. J. (1986). A comparison of two psychological treatments for bulimia nervosa. Behaviour Research and Therapy, 24, 629-643.

Fairburn, C. G., Norman, P.A., Welch, S. L., O'Connor, M. E., Doll, H. A., \& Peveler, R. C. (1995). A prospective study of outcome in bulimia nervosa and the long-term effects of three psychological treatments. Archives of General Psychiatry, 52, 304-312.

Freeman, C. P. L., Barry, F., Dunkeld-Turnbull, J., \& Henderson, A. (1988). Controlled trial of psychotherapy for bulimia nervosa. British Medical Journal, 296, 521-525.

Garner, D. M., \& Garfinkel, P. E. (1979). The eating attitudes test: An index of the symptoms of anorexia nervosa. Psychological Medicine, 10, 647-656.

Garner, D. M., Rockert, W., Davis, R., Garner, M. V., Olmstead, M. P., \& Eagle, M. (1993). Comparison of cognitive-behavioral and supportive-expressive therapy for bulimia nervosa. American Journal of Psychiatry, 150, 37-46.

Geist, R., Heinmaa, M., Stephens, D., Davis, R., \& Katzman, D. K. (2000). Comparison of family therapy and family group psychoeducation in adolescents with anorexia nervosa. Canadian Journal of Psychiatry, 45, 173-178.

Goldbloom, D. S., Olmstead, M., Davis, R., Clewes, J., Heinmaa, M., Rockert, W., et al. (1997). A randomized controlled trial of fluoxetine and cognitive behavioral therapy for bulimia nervosa: Short-term outcome. Behaviour Research and Therapy, 35, 803-811.

Gorin, A. A., le Grange, D., \& Stone, A. A. (2003). Effectiveness of spouse involvement in cognitive behavioral therapy for binge eating disorder. International Journal of Eating Disorders, 33, 421-433.

Griffiths, R. A., Hadzi-Pavlovic, D., \& Channon-Little, L. (1994). A controlled evaluation of hypnobehavioural treatment for bulimia nervosa: Immediate pre-post treatment effects. European Eating Disorders Review, 2, 202-220. 
Halmi, K. A., Agras, W. S., Crow, S., Mitchell, J., Wilson, T., Bryson, S. W., et al. (2005). Predictors of treatment acceptance and completion in anorexia nervosa. Archives of General Psychiatry, 62, 776-781.

Huon, G. F., \& Brown, L. B. (1985). Evaluating a group treatment for bulimia. Journal of Psychiatric Research, 19, 479-483.

Jacobi, C., Dahme, B., \& Dittmann, R. (2002). Cognitive-behavioral, fluoxetine and combined treatment for bulimia nervosa: Shortand long-term results. European Eating Disorders Review, 10, 179-198.

Keel, P. K., Mitchell, J. E., Davis, T. L., \& Crow, S. J. (2002). Longterm impact of treatment in women diagnosed with bulimia nervosa. International Journal of Eating Disorders, 31, 151-158.

Kirkley, B. G., Schneider, J. A., Agras, W. S., \& Bachman, J. A. (1985). Comparison of two group treatments for bulimia. Journal of Consulting and Clinical Psychology, 53, 43-48.

Kohut, H. (1977). The restoration of the self. New York: International Universities Press.

Kraemer, H. C., Wilson, G. T., Fairburn, C. G., \& Agras, W. S. (2002). Mediators and moderators of treatment effects in randomized clinical trials. Archives of General Psychiatry, 59, 877-883.

Kreitler, S., \& Kreitler, H. (1990). The cognitive foundations of personality traits. New York: Plenum.

Laessle, R. G., Beumont, P. J. V., Butow, P., Lennerts, W., O'Connor, M., Pirke, K. M., et.al. (1991). A comparison of nutritional management with stress management in the treatment of bulimia nervosa. British Journal of Psychiatry, 159, 250-261.

Lee, N. F., \& Rush, A. J. (1986). Cognitive-behavioral group therapy for bulimia. International Journal of Eating Disorders, 5, 599-615.

Le Grange, D., Crosby, R. D., Rathouz, P. J., \& Leventhal, B. L. (2007). A randomized controlled comparison of family-based treatment and supportive psychotherapy for adolescent bulimia nervosa. Archives of General Psychiatry, 64, 1049-1056.

Le Grange, D., Eisler, I., Dare, C., \& Russell, G. F. M. (1992). Evaluation of family treatments in adolescent anorexia nervosa: A pilot study. International Journal of Eating Disorders, 12, 347-357.

Leitenberg, H., Rosen, J. C., Gross, J., Nudelman, S., \& Vara, L. S. (1987). Exposure plus response-prevention treatment of bulimia nervosa. Journal of Consulting and Clinical Psychology, 56, 535-541.

Leon, G. R., Fulkerson, J. A., Perry, C. L., Keel, P. K., \& Klump, K. L. (1999). Three to four year prospective evaluation of personality and behavioral risk factors for later disordered eating in adolescent girls and boys. Journal of Youth \& Adolescence, 28, 181-196.

Levine, M. D., Marcus, M. D., \& Moulton, P. (1996). Exercise in the treatment of binge eating disorder. International Journal of Eating Disorders, 19, 171-177.

Lock, J., Agras, W. S., Bryson, S., \& Kraemer, H. C. (2005). A comparison of short- and long-term family therapy for adolescent anorexia nervosa. Journal of the American Academy of Child \& Adolescent Psychiatry, 44, 632-639.

Lock, J., Couturier, J., \& Agras, W. S. (2006). Comparison of longterm outcomes in adolescents with anorexia nervosa treated with family therapy. Journal of the American Academy of Child and Adolescent Psychiatry, 45, 666-672.

Lock, J., \& le Grange, D. (2001). Can family based treatment of anorexia nervosa be manualized? Journal of Psychotherapy Practice \& Research, 10, 253-261.

Lock, J., le Grange, D., Agras, W. S., \& Dare, C. (2001). A treatment manual for anorexia nervosa: A family-based approach. New York: Guilford.

Mazure, S., Halmi, C., \& Einhorn, A. (1995). The Yale-Brown-Cornell eating disorder scale: A new scale to assess eating disorder symptomatology. International Journal of Eating Disorders, 18 237-245.

McIntosh, V. W., Jordan, J., Carter, F. A., Luty, S. E., McKenzie, J. M., Bulik, C. M., et al.(2005). Three psychotherapies for anorexia nervosa: A randomized, controlled trial. American Journal of Psychiatry, 162, 741-747.

Minuchin, S., Rosman, B. L., \& Baker, L. (1978). Psychosomatic families: Anorexia nervosa in context. Cambridge, MA: Harvard University Press.

Mitchell, J. E., Pyle, R. L., Eckert, E. D., Hatsukami, D., Pomeroy, C., \& Zimmerman, R. (1990). A comparison study of antidepressants and structured intensive group psychotherapy in the treatment of bulimia nervosa. Archives of General Psychiatry, 47, 149-157.

Mitchell, J. E., Pyle, R. L., Pomeroy, C., Zollman, M., Crosby, R., Seim, H., et al. (1993). Cognitive-behavioral group psychotherapy of bulimia nervosa: Importance of logistical variables. International Journal of Eating Disorders, 14, 277-287.

Nathan, P. E., \& Gorman, J. M. (Eds.). (2002). A guide to treatments that work (2nd ed.). New York: Oxford University Press.

Nicholls, D., Chater, R., \& Lask, B. (2000). Children into the DSM don't go: A comparison of classification systems for eating disorders in childhood and early adolescence. International Journal of Eating Disorders, 28, 317-324.

Okamoto, A., Yamashita, T., Nagoshi, Y., Masui, Y., Wada, Y., Kashima, A., et al. (2002). A behavior therapy program combined with liquid nutrition designed for anorexia nervosa. Psychiatry and Clinical Neurosciences, 56, 515-520.

Ordman, A. M., \& Kirschenbaum, D. S. (1985). Cognitive-behavioral therapy for bulimia: An initial outcome study. Journal of Consulting and Clinical Psychology, 53, 305-313.

Palmer, R. L., Birchall, H., McGrain, L., \& Sullivan, V. (2002). Selfhelp for bulimic disorders: A randomized controlled trial comparing minimal guidance with face-to-face or telephone guidance. British Journal of Psychiatry, 181, 230-235.

Perpina, C., Botella, C., Banos, R., Marco, H., Alcaniz, M., \& Quero, S. (1999). Body image and virtual reality in eating disorders: Is exposure to virtual reality more effective than the classical body image treatment? Cyberpsychology and Behavior, 2, 149-155.

Peterson, C. B., Mitchell, J. E., Engbloom, S., Nugent, S., Mussell, M. P., Crow, S. J., et al. (1998). Binge eating disorder with and without a history of purging symptoms. International Journal of Eating Disorders, 24, 251-257.

Pike, K. M., Walsh, B. T., Vitousek, K., Wilson, G. T., \& Bauer, J. (2003). Cognitive behavior therapy in the posthospitalization treatment of anorexia nervosa. American Journal of Psychiatry, 160, 2046-2049.

Robin, A. L., Siegel, P. T., Moye, A. W., Gilroy, M., Dennis, A. B., \& Sikand, A. (1999). A controlled comparison of family versus individual therapy for adolescents with anorexia nervosa. Journal of the American Academy of Child and Adolescent Psychiatry, 38, 14821489.

Rosenthal, R., \& Rosnow, R. L. (1991). Essentials of behavioral research methods and data analysis (2nd ed.). Boston: McGraw-Hill.

Russell, G. F. M., Szmukler, G. I., Dare, C., \& Eisler, I. (1987). An evaluation of family therapy in anorexia nervosa and bulimia nervosa. Archives of General Psychiatry, 44, 1047-1056.

Safer, D. L., Telch, C. F., \& Agras, W. S. (2001). Dialectical behavior therapy for bulimia nervosa. American Journal of Psychiatry, 158 , 632-634.

Schmidt, U., Lee, S., Beecham, J., Perkins, S., Treasure, J., Yi, I., et al. (2007) . A randomized controlled trial of family therapy and cognitive behavioral therapy guided self-care for adolescents with bulimia nervosa and related disorders. American Journal of Psychiatry, 164, $591-598$ 
Schmidt, U., \& Treasure, J. (1997). Getting better bit(e) by bit(e): A treatment manual for sufferers of bulimia nervosa. Hove, UK: Psychology Press.

Serfaty, M. A., Turkington, D., Heap, M., Ledsham, L., \& Jolley, E. (1999). Cognitive therapy versus dietary counseling in the outpatient treatment of anorexia nervosa: Effects of the treatment phase. European Eating Disorders Review, 7, 334-350.

Shafran, R., Keel, P. K., Haedt, A., \& Fairburn, C. G. (in press) . Psychological treatments for eating disorders. In K. Halmi \& U. Schmidt (Eds.), Cambridge handbook of effective treatments in psychiatry, eating disorders. Cambridge, UK: Cambridge University Press.

Spangler, D. L., Baldwin, S. A., \& Agras, W. S. (2004). An examination of the mechanisms of action in cognitive behavioral therapy for bulimia nervosa. Behavior Therapy, 35, 537-560.

Telch, C. F., Agras, W. S., \& Linehan, M. M. (2001). Dialectical behavior therapy for binge eating disorder. Journal of Consulting and Clinical Psychology, 69, 1061-1065.

Telch, C. F., Agras, W. S., Rossiter, E. M., Wilfley, D., \& Kenardy, J. (1990). Group cognitive-behavioral treatment for the nonpurging bulimic: An initial evaluation. Journal of Consulting and Clinical Psychology, 58, 629-635.

Thackwray, D. E., Smith, M. C., Bodfish, J. W., \& Meyers, A. W. (1993). A comparison of behavioral and cognitive-behavioral interventions for bulimia nervosa. Journal of Consulting and Clinical Psychology, 61, 639-645.

Thompson-Brenner, H., Glass, S., \& Westen, D. (2003) . A multidimensional meta-analysis of psychotherapy for bulimia nervosa . Clinical Psychology: Science \& Practice, 10, 269-287.

Treasure, J. L., Katzman, M., Schmidt, U., Troop, N., Todd, G., \& de Silva, P. (1999). Engagement and outcome in the treatment of bulimia nervosa: First phase of a sequential design comparing motivation enhancement therapy and cognitive behavioural therapy. Behaviour Research and Therapy, 37, 405-418.

Treasure, J., Schmidt, U., Troop, N., Tiller, J., Todd, G., Keilen, M., et al. (1994). First step in managing bulimia nervosa: Controlled trial of therapeutic manual. British Medical Journal, 308, 686-689.

Treasure, J., Schmidt, U., Troop, N., Tiller, J., Todd, G., \& Turnbull, S. (1996). Sequential treatment for bulimia nervosa incorporating a self-care manual. British Journal of Psychiatry, 168, 94-98.

Treasure, J., Todd, G., Brolly, M., Tiller, J., Nehmed, A., \& Denman, F. (1995). A pilot study of randomized trial of cognitive analytical therapy vs. educational behavioral therapy for adult anorexia nervosa. Behaviour Research and Therapy, 33, 363-367.

Walsh, B. T., \& Kahn, C. B. (1997). Diagnostic criteria for eating disorders: Current concerns and future directions. Psychopharmacology Bulletin, 33, 369-372.

Walsh, B. T., Wilson, G. T., Loeb, K. L., Devlin, M. J., Pike, K. M., Roose, S. P., et al. (1997). Medication and psychotherapy in the treatment of bulimia nervosa. American Journal of Psychiatry, 154, 523-531.

Wilfley, D. E., Agras, W. S., Telch, C. F., Rossiter, E. M., Schneider, J. A., Cole, A. G., et al. (1993). Group cognitive-behavioral therapy and group interpersonal psychotherapy for the nonpurging bulimic individual: A controlled comparison. Journal of Consulting and Clinical Psychology, 61, 296-305.

Wilfley, D. E., Welch, R. R., Stein, R. I., Spurrell, E. B., Cohen, L. R., Saelens, B. E., et al. (2002). A randomized comparison of group cognitive-behavioral therapy and group interpersonal psychotherapy for the treatment of overweight individuals with bingeeating disorder. Archives of General Psychiatry, 59, 713-721.

Wilson, G. T., Eldredge, K. L., Smith, D., \& Niles, B. (1991). Cognitive-behavioral treatment with and without response prevention for bulimia. Behaviour Research and Therapy, 29, 575-583.

Wilson, G. T., Fairburn, C. G., Agras, W. S., Walsh, B. T., \& Kraemer, H. (2002). Cognitive behavior therapy for bulimia nervosa: Time course and mechanisms of change. Journal of Consulting and Clinical Psychology, 70, 267-274.

Wolf, E. M., \& Crowther, J. H. (1992). An evaluation of behavioral and cognitive-behavioral group interventions for the treatment of bulimia nervosa in women. International Journal of Eating Disorders, $11,3-15$. 
Copyright of Journal of Clinical Child \& Adolescent Psychology is the property of Lawrence Erlbaum Associates and its content may not be copied or emailed to multiple sites or posted to a listserv without the copyright holder's express written permission. However, users may print, download, or email articles for individual use. 